\title{
Managing Legal Knowledge in Early Modern Times: Martín de Azpilcueta's Manual for Confessors and the Phenomenon of Epitomisation
}

\author{
Manuela Bragagnolo
}

\section{Introduction: Anatomy of a Pragmatic Book}

Pragmatic books related to moral theology, pastoral, and catechetical literature were widespread in the early modern Ibero-American world. But this literary or, we could say, "editorial genre" - to employ a category which scholars have recently been focusing on ${ }^{1}$ - did not raise the attention of legal historians for a long time because of its apparent simplicity and lack of learned knowledge. ${ }^{2}$ This chapter aims to look inside one of these pragmatic books in order to understand the knowledge base of the pragmatici. We will see that pragmatic books, dealing with moral theological topics, could be very learned.

In particular, I propose to analyse one the most famous and most successful pragmatic books, the Manual for Confessors (Manual de Confessores), written by the celebrated Spanish canon law professor, Martín de Azpilcueta. The text was a real best seller: Emilio Dunoyer counted eighty-one editions printed in Portuguese, Spanish and Latin, between 1549 and 1625, in addition to at least ninety-two editions, if we count the compendia and the Italian translations. ${ }^{3}$ This incredible number of editions and translations was probably related to both the importance of the author, who was an undeniable authority in his time $^{4}$ (named as "iuris monarcha", he was considered as a living legal library), ${ }^{5}$

1 See, for instance, Réach-Gnô, "De la catégorisation bibliothéconomique du livre à la genèse éditoriale de l'oeuvre".

2 For a broad discussion on pragmatic normative literature, see the introduction in the current volume by Thomas Duve (Chapter 1).

3 Dunoyer, L"Enchiridion Confessariorum' de Navarro, 77-108.

4 On the relation between "authorship" and "authority" in early modern legal books, see Beck Varela, "The Diffusion of Law Books in Early Modern Europe", 203-213.

5 Ramlotaeus, Vita excellentissimi iuris monarchae Martini ab Azpilcueta Doctoris Navarri: "Ipse vero lectione assidua, \& meditatione diuturna, pectus suum fecit bibliothecam iuris".

(C) MANUELA BRAGAGNOLO, 2020 | DOI:10.1163/9789004425736_007

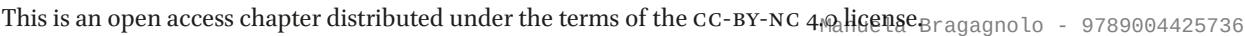


and to a series of different factors directly connected to the Manual: its peculiar nature of Luso-Spanish and then Roman text, its fundamental value in Counter-Reformation Europe (spreading from the first results of the Council of Trent) and the fact that it was able to meet needs that were considered particularly urgent.

The Manual, in fact, soon became a reference work in the courts of conscience both in Europe and in missionary contexts in the frontier regions of the early modern empires. It was a fundamental text for the education of confessors and was also adopted as an official manual by the Jesuits, who used it in their lessons, thus contributing to the development of moral theology as a discipline. ${ }^{6}$ Moreover, it was the first manual used in the new Tridentine seminars and the basis for the diocesan discussions established by the Council of Trent on cases of conscience. ${ }^{7}$ At the same time, as I said, it was very important in the missionary context of the Spanish and Portuguese Empires. ${ }^{8}$ In Goa, as well as in Japan, the Manual was a primary resource; ${ }^{9}$ moreover, it was a real best seller in the New World, omnipresent in the Mexican and in the Peruvian book trades, in the personal libraries of priests with little formal education, and in seminary libraries. ${ }^{10}$ In Mexico and Guatemala, it was highly recommended as a fundamental text for the confession of indigenous people..$^{11}$

It is clear that neither the author nor the Manual are a new object of study; many different aspects of Azpilcueta's intellectual production have been deeply analysed on topics ranging from his contribution to economic thinking ${ }^{12}$ to his political thought; ${ }^{13}$ from the relevance of the Manual for the elaboration of

6 Angelozzi, "L'insegnamento dei casi di coscienza nella pratica educativa della Compagnia di Gesù", 143-144; O'Malley, The First Jesuits, 146.

7 Prodi, Settimo non rubare, 225; O'Banion, “'A priest who appears good' ", 336.

8 Barros, "Intérpretes e confessionários como expressões de politicas linguísticas da Igreja voltadas à confissão", 293. On the influence of Azpilcueta's Manual on the directory for confessors and penitents of the Third Mexican Provincial Council, see the contribution in this volume by Osvaldo R. Moutin (Chapter 8).

9 Barros, "Intérpretes e confessionários como expressões de politicas linguísticas da Igreja voltadas à confissão". See also Wicki (ed.), Documenta Indica, vol. 3, 153; Wicki and Gomes (eds.), Documenta Indica, vol. 16, 639; López Gay, "La primera biblioteca de los Jesuítas en el Japón (1556)", 364-365.

10 O'Banion, “'A priest who appears good'", 336.

11 Barros, "Intérpretes e confessionários como expressões de politicas linguísticas da Igreja voltadas à confissão", 293. Cfr. Baciero, "La obra y sus fuentes", 65 .

12 Muñoz de Juana, Moral y economía en la obra de Martín de Azpilcueta; Afanaseyev, "La Escuela de Salamanca del siglo XVI".

13 Dios de Dios, "La doctrina sobre el poder del príncipe en Martín de Azpilcueta". 
contract law ${ }^{14}$ to its contribution to the debate about the validity of positive law in the court of conscience, ${ }^{15}$ to mention just a few.

Even though many studies have been conducted, one question still remains: why was this manual so successful? In the following pages, I will try to analyse the reasons for its success, firstly by looking closely into the Manual, with an attentive eye to the ways in which knowledge and, in particular, learned normative knowledge (from canon law and civil law) was organised and condensed into a pragmatic manual for confessors. Condensing and epitomising knowledge was a common practice in early modern times, handed down from late antiquity and the Middle Ages. This practice, related to both didactic and professional purposes, was also used in legal and catechetical literature. But this process of condensation from a learned legal text to a pragmatic book did not end, in the case of Azpilcueta, with a static or crystallised work. Studying Azpilcueta's Manual as a material object and following its transformations into the different editions and translations, we will see that the Manual was a living text, in which canon law was constantly interrogated, interpreted, and updated in order to give answers to the burning questions of a rapidly changing world.

\section{Pragmatic Books and Law: Epitomisation of Legal Knowledge in the Early Modern Period}

\subsection{Law and Moral Theology: the "Specific" Literature for Confessors}

As I mentioned before, legal historians did not pay much attention to pragmatic literature, whose lack of learned legal knowledge made it appear weak in terms of canon law and theology to a critical eye. This was, even more, the case for a particular kind of pragmatic book, the specific literature for confessors, which was long considered to only relate to the forum internum, giving a kind of Catholic deontology, and dealing exclusively with morals. But such was not exactly the case.

Early modern literature dedicated to confession, handed down from the late medieval tradition of summae confessorum, was mainly composed of small texts to be used by all priests, especially those who heard confessions. This literature could also count big structured texts with a rich casuistry, but the little manuals were largely more common. ${ }^{16}$ These were "practical" books, "designed

\footnotetext{
14 Decock, Theologians and Contract Law.

15 Lavenia, L'infamia o il perdono; Condorelli, "Le origini teologico-canonistiche della teoria delle leges mere poenales (secoli XIII-XVI)".

16 Michaud-Quantin, Sommes de casuistique et manuels de confession au moyen âge, 9-10.
} 
for use", ${ }^{17}$ in which the confessor could find instructions for best administering the sacrament of penance, following, in particular, the order of the seven sins and of the Decalogue. They were compendia of dogmatic-moral principles and, at the same time, practical manuals, with many useful indications - on the process of interrogating a penitent as well as on the penance to be imposed.

During and after the Council of Trent, the attention on the education of priests contributed to a perceived need for tools to implement the decrees on penance. In this respect, numerous practical instructions were printed, to explain the way in which confessors ought to interact with the penitent, such as the Avvertimenti by Federico Borromeo (1574). ${ }^{18}$ Moreover, many late medieval summae were updated in line with the decrees of the Council of Trent, later becoming classics of the post-Tridentine literature. ${ }^{19}$ The result was an explosion of manuals for confessors and cases of conscience in the post-Tridentine period, that lead to the need for brevity, selection, and reorganisation of the material in a more efficient way. ${ }^{20}$

A strong intertwining between law and morality characterised this literature for confessors since its origins. ${ }^{21}$ Medieval Summae and manuals for confessors, in fact, were not only often written by jurists but also contained a juridical discourse with solid theological bases. From the perspective of avoiding sin ("ratio peccati vitandi"), the Summae confessorum provided deep analysis of the legal relationships governing medieval Christian societies. ${ }^{22}$ The casuistic approach, which characterized many of these works, allowed very profound examination of legal institutions, especially those dealing with contracts, which become the most important part of the summae concerning the seventh commandment, "do not steal".23 The solution of moral theological questions was based on civil and canon law. ${ }^{24}$

17 Tentler, Sin and Confession in the Eve of the Reformation, 48-53. See also Blanco, Historia del confesionario.

18 Boer, The Conquest of the Soul.

19 Turrini, La coscienza e le leggi, 72.

$20 \quad$ Turrini, La coscienza e le leggi, 68.

21 On the legal bases of the literature for confessors, see Michaud-Quantin, Sommes de casuistique et manuels de confession au moyen âge; Grossi, "Somme penitenziali, diritto canonico, diritto comune", 1966, then reprinted as Grossi, "Somme penitenziali, diritto canonico, diritto comune", 2013: for this work I consulted this edition; Prodi, Una storia della giustizia, $87-92$.

22 Grossi, "Somme penitenziali, diritto canonico, diritto comune", 143.

23 Prodi, Settimo non rubare, $115^{-121 .}$

24 It has been stressed that, drawing largely on Roman and Canon law, and, at the same time, being directly related to the concrete practice of confession, this literature became a privileged way in which ius commune reached the lower levels of society. See also Goering, 
The connection between law and moral theology grew stronger in the Catholic tradition with the Council of Trent, which "affirmed and reinforced the tendency within the late medieval manuals for confessors to use legal argument as an essential tool in solving cases of conscience". ${ }^{25}$ But this strong intertwining of canon law, civil law and moral theology, this "symbiosis"26 between law and morality, was already a trend, particularly in the Spanish legal culture: that can be clearly seen in Azpilcueta's works, namely in his Manual.

The portrait depicted by Beyerlinck in his Magnum theatrum vitae humanae (1631) is clear in this regard; Azpilcueta was the best theologian among jurists and the best jurist among theologians. ${ }^{27}$ What has not been analysed until now, though, is the process through which canon and civil law were transferred and translated from the erudite legal books in universities to practical manuals, which were conceived for use by confessors and penitents. This process, which is the main object of these pages, can be described by the word 'epitomisation'.

\subsection{Epitomising Legal Knowledge}

In the early modern period, epitomising was a common practice. Drawing on traditions from late antiquity and the Middle Ages, this process was greatly developed during the Renaissance. ${ }^{28}$ The making of epitomae and compendia of already existing texts, thus selecting, condensing and briefly summarising them, as well as compiling different works by providing excerpts from them in a convenient and pre-digested way, were among several techniques used for managing scholarly information. ${ }^{29}$ The aim of brevity went hand in hand with the will of excerpting only what was considered important and interesting for the reader, while organising the information conveniently in a clear way. This went along with new attitudes toward page layouts (like the creation

"The Internal Forum and the Literature of Penance and Confession", 405-406. See also Decock, Theologians and Contract Law, 46 .

25 Decock, Theologians and Contract Law, 55.

26 Decock, Theologians and Contract Law, 44. On the "cross-fertilization between the ius commune, the canon law and the moral theological literature" which characterized the "syncretic nature of the Spanish legal culture of the early modern period", see Decock, Theologians and Contract Law, 40.

27 Beyerlinck, Magnum theatrum vitae humanae, vol. 4, parte II, 468.

28 On the different techniques and aims of epitomisation of Latin legal texts of late antiquity and the early modern period, see Christoph H.F. Meyer's contribution (Chapter 2) in this volume.

29 On "compilers, their motivations and methods", see Blair, Too Much to Know, 173-229; Hamesse, "Il modello della lettura nell'età della scolastica", 103-108. See also Minnis, "Late Medieval Discussions on Compilatio and the Role of Compilator", $386-387$; Cevolini, De arte excerpendi. 
of indexes, chapter headings lists, and other finding devices), whose potential was largely developed with the printing press. ${ }^{30}$

Jurists largely practiced the compilation and epitomisation of knowledge. Collecting, selecting and summarising were techniques particularly used in the Middle Ages and in the early modern period, when jurists had to deal with a large number of "universal" corpora of civil and canon law and, for that reason, they elaborated tools and memory devices (like promptuaries, alphabetic dictionaries, florilegia and summae) for accessing to these corpora, always subscribing to the idea of having an entire library in one book. Therefore, in the 16th century epitomae were a specific category for the organisation of knowledge, directly associated with law and the specific literature for confession. That can be illustrated by Conrad Gessner's Pandectae (1548-49), the work that organised by subject the huge bibliographic material of his Bibliotheca Universalis (1545). In the section dedicated to civil and "Pontifical" law, Gessner mentions the "epitomae in utroque", in which he refers to legal compendia and promptuaries and to the summae confessorum. ${ }^{31}$

What Azpilcueta did in writing his manual belonged somehow to this intellectual universe of making epitomae and, if we believe Azpilcueta's first biographer, those who possessed the Manual could say to have an entire library in their hand. ${ }^{32}$ In his Manual, in fact, Azpilcueta briefly and clearly explained "breve", "brevedad", "breves y claras", "brevissimamente", "affectata brevitas", are words quoted more and more often in the paratexts, in the different editions of the book ${ }^{33}$ - a large body of knowledge, which was needed to resolve new

$30 \quad$ Rouse and Rouse, "Statim invenire", 201-225.

31 Gessner, Pandectarum sive partitionum universalium Conradi Gesneri Tigurini, lib. XIX, tit. II, 336 .

32 Ramlotaeus, Vita excellentissimi iuris monarchae Martini ab Azpilcueta Doctoris Navarri.

33 The idea of brevity is stressed more and more in the different editions of the Manual. That appears clearly if we look at the prefaces to the readers of the four main editions of the text. In the 1549 edition (El doctor Martín de Azpilcueta Navarro al lector, in: MC1549), Azpilcueta recalls the sweet brevity ("dulce brevedad") with which the anonymous Franciscan friar treated both general and particular matters in this first edition of the Manual. In the $155^{2}$ edition (Al pio lector, el doctor Martín de Azpilcueta Navarro. Salud, MC, 1552) the idea of brevity appears much more often, as an effect of the complex process of transformation and revisions he made to the Manual, in which he very briefly ("brevissimamente") gave evidence of the arguments he mentions in the Manual on the hard and huge matters of cases in theology, canon law and civil law. He recalls the briefness needed ("summa brevedad") and describes the pages as brief and clear ("breves y claras"). We can find these two last statements also in the 1556 edition (Al pio Lector, el doctor Martín de Azpilcueta Navarro. Salud. en N.S. Iesu Christo, MC1556), in which Azpilcueta mentions the style of affected brevity ("estilo dela brevedad affectada") which characterised the Manual; he recalls also a special section of the Reportorio, added in this 
and complicated cases. As we hear in Azpilcueta's own words, confessors were asked to manage a large body of knowledge, especially in larger spaces like a kingdom or in complex and new situations like in the Americas ("En una India"), or in places in which there was no learned person to be consulted for advice. ${ }^{34}$ For this reason, having a brief and clear text was particularly important.

However, the Manual was addressed not only to confessors (who remained the principal target readers of this kind of books); in fact it was conceived as reaching different kinds of readers and having different levels of reading. As Azpilcueta says in the dedication to the reader, the book was a Manual of Christian doctrine for everybody, an inventory and memory tool concerning conscience for learned people, and finally, a treatise with the rules for confessing and being confessed, addressed to both confessors and penitents. ${ }^{35}$ And this implied different levels of epitomisation of learned knowledge.

In the specific case of Azpilcueta's Manual, the epitomisation of normative knowledge involved different intellectual processes. Not only did it mean collecting, selecting, organising systematically and condensing, but also translating and updating all the normative knowledge concerning conscience in one book (transformed many times), whilst combining the transformations of the text with the self-translation of the Manual into different languages. On the one hand, epitomisation went hand in hand with a very special process of cultural translation of legal ideas. ${ }^{36}$ While condensing and summarising the content, Azpilcueta translated learned canon law knowledge from the Latin of his university courses to the vernacular language of the Manual, thus adapting the technical words of canon and civil law to the practical application in confession. On the other hand, the condensation of normative knowledge was a dynamic and diachronic process, achieved in the many transformations, translations and updates of the Manual, which were directly connected with Azpilcueta's travels, as well as with the questions related to newer and more

edition, which could serve as brief memory tool ("breve memoria", "memorial breve") for both penitents (for remembering their sins) and confessors (for examining the penitent). The idea of affected brevity ("affectatae brevitatis") appears twice also in the Latin edition (Candido Pioque lectori, EC1573).

$34 \mathrm{MC} 1552$, cap. 4, § 4, 28; MC1556, cap. 4, § 4, 27; EC1573, cap. 4, § 4, $64 \mathrm{v}$.

35 MC1552, Al pio lector, el doctor Martín de Azpilcueta Navarro. Salud: "doctrina Christiana, para todos: memorial y reportorio de lo necessario ala consciencia, para los doctos: Confessionario perfecto, para confessores: espejo de azero, grande y claro para penitentes".

36 On "cultural translation" see Burke, "Cultures of Translation in Early Modern Europe", 9. On the importance of "cultural translation" in legal history, see Duve, "European Legal History". 
complicated cases of conscience presented to Doctor Navarrus from both the Old and the New World. Martín de Azpilcueta, "el mayor teólogo de todos los juristas y el
mayor jurista de todos los teólogos"

It is probably fair to say that Azpilcueta condensed in the Manual the knowledge and the experience of his entire life, a long life in which he was not only a professor of canon law and an advisor, but in which he had the "involuntary chance" to "physically follow" the most relevant passages in the history of the Iberian peninsula and of the Church, moving from one city to another and from a country to another in crucial moments for the religious and political history of the time. ${ }^{37}$

We can identify three moments in Azpilcueta's very long life related to the elaboration, main transformations and translations of the Manual, moments in which Azpilcueta was in direct contact - as an adviser - and consultor with the Portuguese and Spanish Crowns and later with the Roman Curia.

The first period can be related to his activity as a professor of canon law, first in Salamanca (1524-1538) and then in Coimbra (1538-1554), where the first edition of the Manual appears. Coming from a Spanish noble family of the kingdom of Navarra, Azpilcueta studied theology at Alcalá de Henares and law in Toulouse, where he obtained his doctoral degree in canon law, and started his teaching activity in Toulouse and Cahors. Then he moved to Salamanca, where he obtained a second doctoral degree in canon law and then became a professor, holding first the chair of Decretum and then the one of Prima de Canones, the most prestigious chair at that University. ${ }^{38}$ In Salamanca Azpilcueta already showcased some very special features of his teaching, directly connected to his main scholarly interests. First of all, while his colleagues concentrated their teaching on the canons dedicated to the forum externum, namely those matters, which could guarantee an income to canon lawyers, he showed a particular interest for those canons related to spiritual matters and

37 For a comprehensive reconstruction of Azpilcueta's biography and an updated bibliography, see Lavenia, "Martín de Azpilcueta (1592-1586)" (for the quotes, see 71; trans. M.B.); Tejero Tejero, "Azpilcueta, Martín de”; Belda Plans, Martín de Azpilcueta. On Azpilcueta, see now Decock, "Martín de Azpilcueta".

38 Some interesting notes on Azpilcueta's teaching activity in Salamanca are to be found in Rodríguez-San Pedro Bezares and Weruaga Prieto (eds.), Historia de la Universidad de Salamanca, vol. 5, 391-394. See also García y García, "Juristas Salamantinos", 141-142. 
directed to the salvation of the soul. Moreover, he demonstrated his preference for the ius antiquum of the Decretum Gratiani, the ancient canon law, instead of the Decretals, on which, at that time - as he complained many years later, remembering those years - teachers preferred to base their courses, even in the Decretum chair. ${ }^{39}$ Reading Gratian, Azpilcueta focused particularly on the seven Distinctiones on Penance, which are the object of his very well-known commentaries on Gratian's De Poenitentia (1542) ${ }^{40}$ To this period dated also his works on indulgences, his democratic relectio on the royal power, as well as his works on exchange and usury: all topics debated within the School of Salamanca, characterised by a deep and constant thinking on the most current topics of the time. ${ }^{41}$

At the moment of Azpilcueta's greatest success in Salamanca, Charles v decided to send his most celebrated professor to Portugal. For this reason, in 1538, Azpilcueta arrived at the new University of Coimbra, reorganised by João III, King of Portugal, to provide an education for the Portuguese future elites. Here Azpilcueta held the chair of Prima de Canones. The content of the classes was decided by the University Council (and was particularly dedicated to the second book of the Decretals), but he continued to teach extra courses in spiritual matters, which became the bases of his Manual. He also gave daily courses on civil law matters related to canon law. ${ }^{42}$

It is also important to stress, once more, that Azpilcueta's canon law courses were directly related to the urgent and contemporaneous religious topics that often originated from the concrete questions, which crossed the Iberian Peninsula and the early modern Empires. Azpilcueta questioned and interpreted canon law at the university in order to offer solutions to the biggest political and legal questions of the time, like, for instance, the topic of trade with Muslims, which was a crucial aspect of the Portuguese imperial life in the middle of the 16th century. In 1550, for instance, Dom João III, urged on by the Jesuit community, asked Azpilcueta to comment, in his university, upon the chapter Ita quorundam, de judaeis (x, 5.6.6), established at the III Lateran Council by Alexander III. Behind Azpilcueta's relectio there was a concrete question

39 Tejero, "Martín de Azpilcueta en la historia de la doctrina canónica y moral", 455. See Praefatio, in Azpilcueta, Commentaria in septem distinctiones de Poenitentia, 3.

40 Azpilcueta, In tres de poenitentiae distinctiones posteriores commentarii. The commentaries to all the seven distinctiones would be printed in 1581 .

41 Tejero Tejero, "Azpilcueta, Martín de", 430.

42 On Azpilcueta's teaching in Coimbra, see Solinas Quijada, "El doctor Martín de Azpilcueta en la Universidad de Coímbra"; Tejero, "Martín de Azpilcueta cinco veces universitario", $859-862$. 
posed to the King from the frontier regions of the Portuguese Empire (Goa) by the vicario general, Fernandes Sardinha. ${ }^{43}$ This question raised a huge debate in Portugal and provided Doctor Navarrus the occasion for his lecture, later printed in 1550. In the dedication to Simão Rodrigues (the superior of the Jesuit Province of Portugal), Azpilcueta underlined that several questions related to this topic had also been posed not only by Jesuits in Africa, but also by Manuel da Nóbrega and Azpilcueta's nephew, Juan, in their letters from Brazil. ${ }^{44}$ Two years later, Azpilcueta would have constantly referred to this text, as well as to his other books related to his teaching of canon law at the university, in his Manual for confessors.

In this period, in fact, Doctor Navarrus was closely connected to the new Jesuit communities. In particular, he was in contact with the Jesuits sent out to set up the first mission in Brazil (1549), namely with Nóbrega, the leader of that mission, and with Azpilcueta's nephew, Juan. Azpilcueta was particularly close to Juan, who had been living together with him, in the same house, for many years. ${ }^{45}$ Both Jesuits had been his students in Coimbra and, as we can guess from the mentioned preface to the Reader of the mentioned Relectio of $155^{\circ}$, they maintained epistolary communication with their professor and friend as soon as they reached the Brazilian coasts. Azpilcueta, on the other hand, proved to be an important point of reference for the solution of crucial topics in the Portuguese mission in Brazil.

During his stay at Coimbra, Azpilcueta became closely related to the Portuguese Crown, being named the King's advisor in canon law matters as well as the Confessor of Charles v's daughter Doña Juana, the "princess of the Catholic reformation" who was married to Prince João of Portugal in $155^{2 .}{ }^{46}$ When the princess of Portugal and Queen of Spain became regent of Castile in 1554, Azpilcueta returned to Spain. These years in Spain (1554-1567), when he became an advisor to the Spanish Crown, mark the second period of Azpilcueta's life.

43 Marcocci, Linvenzione di un impero, 90-107.

44 Eruditissimo viro magistro Symoni Roderico, in Azpilcueta, Relectio cap. ita quorundam de Iudaeis: "Quaestiones item illae, quas perdoctus Emanuel a pridem a nobis laurea donatus, religione, doctrina, \& genere clarus, \& Ioannes ab Azpilcueta, meus ex fratre nepos chiarissimus ex Brasilia: quo eos ad negotia Iesu Christi agenda misistis, ante annum suis literis interrogarun".

45 Cardoso, "IV Centenario do P. João de Azpilcueta Navarro", 16. On Juan de Azpilcueta see also Palacín, "Azpilcueta (Navarro), Juan de", 317.

46 On Juana de Austria, regent in Spain (1554-1559) during the absence of Philip II, see Bataillon, "Jeanne d'Autriche, Princesse de Portugal", 283. 
Finally, in 1567 , following the trial of the Archbishop of Toledo, Bartolomé de Carranza, Azpilcueta moved to Rome, where he lived for his remaining 19 years, working as a consultor at the Court of the Apostolic Penitentiary. His stay in Rome (1567-1586) marks the third important phase of our periodisation.

\section{The Printing Press as a Tool? Looking at Azpilcueta's Manual as a Material Object}

I insisted on Azpilcueta's biography because this information is particularly important not only to understand the kind of knowledge Doctor Navarrus condensed in his Manual, but also because the most important transformations of the Manual are strictly related to his biography and travels. The epitomisation of normative knowledge was a dynamic process, which went hand in hand with, and was made through, these different editions and translations. For this reason, before presenting my hypothesis concerning the strategies that Azpilcueta adopted for epitomising and condensing normative knowledge within the Manual, it is important to look at the different editions, and take into account the transformations and the evolution of the book, bearing in mind the author's moves from Portugal to Spain and Rome. I shall consider only a few of those editions which marked major changes, and in which the transformations of the text were accompanied by Azpilcueta's self-translations of the Manual. Its author requested, as we will see, the privilege of print for better controlling the editorial process.

\subsection{From a Small Book to a Big One: Self-Translation}

If we turn to the editorial history of the book, from a diachronic perspective we can perceive an evolution of the text, from a small and relatively thin book, printed in octavo and written in vernacular language (initially in Portuguese), to a big and much thicker one, in quarto, finally written in Latin. What traditionally has been considered "the" Manual of Azpilcueta, were, in fact, several different texts. Azpilcueta himself, in the paratexts, took care of informing the reader about the transformations of the text as well as - we will see this later on the intellectual process, which stood behind them. As we can read in the preface to the reader of the 1556 edition, the Manual had grown from a small book, "pequeño", into a big one: "hezimos este grande". 4

47 Martín de Azpilcueta, Al pio Lector, el Doctor Martín de Azpilcueta Navarro, Salud. en N.S. Iesu Christo, in MC1556. 
It is particularly important to consider Azpilcueta's Manual as a material object, keeping in mind the differences from one edition of the Manual to another - not so stressed by the historiography until now - which can help in reconstructing the evolution of the author's thinking. These differences are directly connected to the essential instability of early modern printed books, in which the "fixity" of a text was not an "inherent' quality", but rather a "transitive' one". ${ }^{48}$ Once printed, early modern books were often rethought and reorganised - also in the light of other books printed at the same time. ${ }^{49}$ This instability was a feature, depending not only on the author's intention but also on external reasons more related to the printer's technical and economic needs. The multiplicity of actors involved in the printing process, which somehow complicated the topic of the "authorship" in the early decades of the printing press, contributed to this instability, which also impacted the "readership" of the book and its use. In the case of Azpilcueta's Manual, we can add to this instability the author's purpose of transforming and updating the text. Here we can probably adopt Anne Blair's words that the printing press was a "tool", which influenced the author's method as well. ${ }^{50}$

As I said, these main transformations and updates appeared in the translation process, which was - to mention an interesting category to which scholars have recently paid attention - a process of "self-translation" (or, as we will see, a «collaborative» one). ${ }^{51}$ Self-translation, "authored by a writer who can compose in different languages and who translates his or her text from one language into another [...] was a common practice in the ambient translingual world of early modern Europe, when bilingualism was the norm and writers increasingly translated between Latin and vernaculars".52 The self-translator was a kind of crosscultural interlocutor, a "language broker" between different cultural parties, who

48 Johns, The Nature of the Book, 19. Only recently legal historian started to pay attention to legal books as material objects, bringing the gap between material bibliography and the history of legal thought. See in particular Hespanha, "Form and content in early modern legal books"; Beck Varela, "The Diffusion of Law Books in Early Modern Europe".

49 Réach-Ngô, "Du texte au livre, et retour", 33.

50 Blair, "Humanism and Printing Press in the Work of Conrad Gessner", 3 o.

51 On the several processes of self and collaborative translations of Azpilcueta's Manual, see Bragagnolo, "Les voyages du droit du Portugal à Rome". On "collaborative translation", see Cordingley and Frigau Manning (eds.), Collaborative Translation.

$5^{2}$ Hokenson and Munson, The Bilingual Text, 1. Bilingualism was the norm between Portuguese and Spanish (both at the Portuguese courts and in the Castilian popular environment) and that not only for the geographical and cultural proximity but also because of the great circulation of people and books. On this point, see Carabias Torres, "Castilla y Portugal”. See also Ridruejo, "Castellano y portugués en la época de los descubrimientos"; Buescu, "Aspectos do Bilinguismo Português-Castelhano na época moderna". 
accorded to himself much more freedom in the translation process than a normal translator. ${ }^{53}$ As we can detect also in Azpilcueta's work, each self-translation produced another version, another "original" of the text, which was connected to the different political and cultural contexts of the author's life (in Portugal, Spain and Rome). The privileges of print granted to Doctor Navarrus for the different editions of the Manual that we consider (which however did not prevent several pirate editions and translations that actually appeared in Spain and Italy) show the intertwining and overlapping of the different political powers, whom the author had asked for protection, very probably in order to better control the publication of his works. ${ }^{54}$ For instance, in addition to the papal privilege of the 1552 Portuguese edition, printed in Coimbra, Azpilcueta received the privileges of Castile, Aragón and Portugal (as he did for the 156o Portuguese translation) for the 1556 Spanish edition, printed in Salamanca. ${ }^{55}$ While the Spanish updates related to the Council of Trent of the 1570 edition, printed in Valladolid and Zaragoza, went hand in hand with a new privilege of Philip II, the 1573 Latin edition was accompanied by a papal privilege, then renovated for the 1584 edition.

\subsection{Traveling Texts in Space and Time: the Manual and its Editorial History}

The Manual had a very complex editorial history. ${ }^{56}$ The starting point can be identified in the 1549 edition, printed in Coimbra by the printers of that University, Ioão da Barreira and Ioão Alvares: a small in octavo book, in Portuguese. ${ }^{57}$ Two aspects related to this edition can be considered as particularly interesting. The first interesting aspect of this edition is that its core part was not

53 Cordingley, "Introduction", 1.

54 For a description of some elements related to the privileges of print of the editions mentioned in this article, see table 6.2.

55 In Spain, book privileges were mainly granted to authors in order to prevent anyone else but the printer they choose to print the text for a certain time, thus giving to the author the chance to supervise the publication. On the Spanish book privilege system, see Mateu y Llopis, "Licencia"; Simón Díaz, El libro español antiguo, 128; Reyes Gómez, "Con privilegio"; Reyes Gómez, "La estructura formal del libro antiguo español", in particular on the privileges granted to Azpilcueta for the ${ }_{155} 6$ Spanish edition of his Manual (that reflected the administrative subdivision of Spain and, as often happened, included also the privilege of Portugal), see 40.

56 For a description of the main editions of Azpilcueta's Manual de Confessores quoted in this article, see table 6.1. For a description of the most important sections of the Manual in the different editions, see table 6.3.

57 MC1549. On the contractual relations between the University and Barreira and Alvares, see Fonseca, Antunes, Vaquinhas, Vargues, Torgal and Regateiro, Imprensa da Universidade de Coimbra, 13-14. 
written by Azpilcueta, but by a Franciscan friar from the Portuguese Provincia da Piedade who, for being extremely humble (humility characterised the members of this Province), remained anonymous. ${ }^{58}$ Who was this author? The historiography has identified him as Rodrigo do Porto, but without providing much more information on him and with some incongruence. ${ }^{59}$ If his identity at the present state of research remains a mystery, it is possible to reconstruct some information on this Province and its importance for the Portuguese Empire, thus infer some hypothesis on the text and its history.

Founded in 1517 by the Franciscan community who came from Spain to Portugal under the protection of duke D. Jaime de Bragança, the Provincia da Piedade (1517) was a Province of strict observance. ${ }^{60}$ The province soon provided many of the Franciscan missionaries for the Portuguese Estado da India. ${ }^{61}$ According to Ângela Barreto Xavier, the text attributed to Rodrigo could be considered an interesting source of information on the specific models of confession concretely practiced by Franciscans in the missionary context. ${ }^{62}$ From this province also came King João III's confessors; ${ }^{63}$ moreover, Cardinal Dom Henrique, king João

58 Silva, "A primeira suma portuguesa de teologia moral e sua relação com o «Manual» de Navarro", 368. Azpilcueta himself underlines that the author preferred to remain anonymous due to great humility: "El autor por su humilidad no quiere nõbrarse". Martín de Azpilcueta, Al muy alto, y muy excellente seõor, el Cardenal Infante don Henrique, in MC1552. For some reflections on the relation between the Franciscan friar's work and Azpilcueta's Manual, see also Dunoyer, L'Enchiridion Confessariorum' de Navarro, 77-84; Fernandes, "Do manual de confessores ao guia de penitentes".

59 See in particular Vilas Boas, Memorias históricas do ministério do púlpito, 142; Machado, Bibliotheca Lusitana, vol. 3, 654; Machado, Bibliotheca Lusitana, vol. 1, 213. On the attribution to Rodrigo do Porto, see also Silva, "A primeira suma portuguesa de teologia moral e sua relação com o «Manual» de Navarro", 368-37o. Recently Rodrigo do Porto has been mentioned as a theology teacher (lente) in 1446. Rodrigues (ed.), Memoria professorum Universitatis Conimbrigensis, vol. 1, 39. If we believe Azpilcueta's explanation on his collaboration with the author of the 1549 edition for preparing the $155^{2}$ edition, this hypothesis seems not to be possible.

6o On the Provincia da Piedade, see Monforte, Chronica da Provincia da Piedade. Guedes de Campos, A ordem das ordens religiosas, 196-208.

61 Amongst the others, in 1546 João III chose from this province six Franciscan friars, to be sent to the Indian mission; two of these returned to Portugal in 1548. The leader of the group was Antonio do Porto who wrote a detailed report of these events to João III on 7 October 1548. See Rëgo (ed.), Documentação para a história das missões do padroado português do Oriente, vol. 3, 258-266, esp. 259-26o; Rëgo (ed.), Documentação para a história das missões do padroado português do Oriente, vol. 4, 16-22; 59-65.

62 Xavier, "Itinerários Franciscanos na Índia Seiscentista e algumas questões de história e de método", 97.

63 Marques, "Franciscanos e Dominicanos Confessores dos Reis Portugueses das duas Primeiras Dinastias", 58 . 
III's younger brother, Archbishop of Evora and Inquisitor General of Portugal, was particularly linked to this Province and their members. ${ }^{64}$

It was Dom Henrique who asked Azpilcueta to read and check for the Inquisition the conformity of "Rodrigo"s text with the Catholic faith, and then to publish it, to connect it with the general reformation of the Portuguese religious life that he aimed at. In fact, not only was Dom Henrique the protagonist of the foundation and spread of the Portuguese Inquisition (1536), which within thirty years had become a powerful machine, but he also promoted the reformation of the religious orders and the secular clergy, paying particular attention to the examination of confessors as well as to the education of the priests, which was perceived as particularly urgent due to the ignorance of the clergy. ${ }^{65}$ For that reason, he promoted and often financed the publication of several books, mainly small promptuaries for confessors: ${ }^{66}$ such as Arte para bem confessar (1537) (a Portuguese translation made by Aires da Costa of a treatise composed by an anonymous Spanish friar, belonging to the order of S. Jerome); a new edition of Sacramental by Sanchez de Vercial (1539), and the Spanish translation by Paulo de Palacio of the Summa Caietana (1557). To these texts, we might add several manuals for confessors, which were more generally printed under the protection of the Portuguese Crown between 1546 and $155^{2} .{ }^{67}$ So Dom Henrique was certainly one of the most active bishops who made a large use of the printing press for the sake of religious reformation in Portugal. ${ }^{68}$ Among these editorial initiatives, the Manual was, with no doubt, the most successful one.

Returning to the author of the Manual, it can be assumed that the anonymous Franciscan friar knew Azpilcueta's work particularly well. Even if, at the present state of research, it is impossible to distinguish with absolute certainty the different parts of the Manual written respectively by 'Rodrigo' and

64 Monforte, Chronica da Provincia da Piedade, 340.

65 Polónia, "Espaços de intervenção religiosa do Cardeal Infante D. Henrique"; Polónia, D. Henrique.

66 On the manuals promoted by Dom Henrique, see Fernandes, "As artes da Confissão", 7679. See also Polónia, "Espaços de intervenção religiosa do Cardeal Infante D. Henrique", 19, 23; Marcocci, I custodi dell'ortodossia, 155-175.

67 Several manuals were dedicated to João III, King of Portugal: Sancho de Noronha's Tractado da segunda parte do sacramento da penitentia, que he confissam (1547); Enchiridion o Manual de Doctrina Christiana (quae tambien puede servir de confissionario), (1552), written by the Dominican Diego de Ximenez, firstly requested by the Fray Juan de Zumarraga, the first archbishop of Mexico. The king directly commissioned Norte de confessores, by João III's chaplain and preacher, the theologian Francisco de Monzón (1546).

68 Paiva, "Bispos, imprensa, livro e censura no Portugal de Quinhentos", 691. 
Azpilcueta (and we have to rely on the printed book), it would not be surprising, for instance, to find him amongst the several Portuguese students who attended his classes at the University of Salamanca or amongst his students in Coimbra. ${ }^{69}$ In fact, in the Manual, he refers largely to Navarrus' works arising from his teaching activity in Salamanca and in Coimbra, namely his commentary to the three last distinctiones De Poenitentia of Gratian's Decretum (1542) as well as his commentary on the chapter Inter verba (1544), printed only some years before. ${ }^{70}$ To 'Rodrigo"s text, Azpilcueta added the explanation of 93 unclear passages of the Manual, which he had been asked to clarify once the 27 chapters of the Manual were printed but not diffused. In this part, he added further references to his learned works. ${ }^{71}$

Concerning this edition, a second aspect is worth mentioning. This edition, accomplished on 27 July 1549, can be described as particularly instable: it was printed with several variants, at the point that amongst the copies today preserved at the National Library of Portugal, two identical copies do not exist. While differences are mainly formal, sometimes the copies differed also in the content. It is the case, for example, of few copies that showcased a supplementary ending folder, containing specific particular questions asked by some prelates. $^{72}$

This edition was followed by a $155^{2}$ Portuguese edition (which was a bit more stable), ${ }^{73}$ in octavo, which grew bigger, and by a ${ }^{5} 553$ Spanish close translation of

69 On the important presence of Portuguese students at the University of Salamanca during the 16th century, see Serrão, "Portugueses no Estudo de Salamanca (1250-1550)". The presence of Rodrigo at the University of Salamanca or Coimbra for the moment has to remain a hypothesis. In Serrão's work, in fact, there is no trace of a Rodrigo coming from Porto amongst the Portuguese students in the years in which Azpilcueta was a professor there.

70 The author apparently knew Azpilcueta's other works very well. He frequently quoted "Navarro", namely his work on De Poenitentia (1542) and Inter Verba (1544). See, for example, MC1549, 25 (in which the author refers to "Navarro's" commentary on ch. Consideret of his commentary De Poenitentia); 263 (in which "Navarro's" Inter verba is quoted).

71 Several printing errors characterise this part of the book, namely the numbers of Azpilcueta's explanations: the last one corresponds to number 9o, but actually there are three more explanations in the section, not correctly numbered.

72 I examined all the copies of the 1549 edition today preserved at the Biblioteca Nacional de Portugal (BNP): Res. 106o P.; Res. 1625 P.; Res. 1662 P.; Res. 2929 P.; Res. 293 O P.; Res. 4722 P.; D.S. XVI-19. Among them, only the two last ones showcased the supplementary folder I mentioned, which is also present in a copy preserved in the Biblioteca Publica Municipal do Porto (в РмР): X-1-3-16.

73 The only variant I found concerned a supplementary folder with "Algumas preguntas acerca dos religiosos. E primeiramente dos prelados" showcased, once again, only in 
it, in quarto. Both of them were published in Coimbra by Barreira and Alvares, who appear in the book as royal printers. This version of 1552/1553 (we know that Azpilcueta and 'Rodrigo' worked contemporarily at the Portuguese and at the Spanish text),${ }^{74}$ which kept the structure in 27 chapters while integrating Azpilcueta's "Declaración", included important revisions of the first text. As we can read in the paratext, Azpilcueta, with the help of 'Rodrigo', worked hard at these modifications, thus producing a completely new version. ${ }^{75}$

After these editions, the text got successively larger and started to be printed mainly in quarto, thus revealing probably a shift in the target reader. ${ }^{76} 1556$ saw a new Spanish edition, printed in Salamanca by the well-known Andrea de Portonaris. ${ }^{77}$ This revision, made with the help of fray Antonio da Zurara, also coming from the Provincia da Piedade, was requested by the King of Spain and featured some major modifications. ${ }^{78}$ Firstly, Azpilcueta added five commentaries on canon law regarding economic matters, printed separately. This edition also contains a sizeable Repertorium, which was also printed separately, together with the Comentarios. Doctor Navarrus additionally provided more solutions to challenging cases of conscience, and updated the text with further references to the decrees of the ongoing Council of Trent. Thanks to Dom Henrique, the directives of the Council circulated quickly from 1553 in Portugal, when Azpilcueta was there. ${ }^{79}$ But Azpilcueta's indirect involvement

few copies preserved in the BNP: Res. 1679//1 P.; Res. 1754//1 P.; and in the врмР: $\mathrm{X}-1-3-17-1$.

74 In the $155^{2}$ preface to the reader, Azpilcueta writes about the new 'edition', a revision of the previous one, as being written both in Portuguese and Spanish. MC1552, Al pio Lector, el doctor Martín de Azpilcueta Navarro.

75 For a reconstruction of the co-authorship of the revisions of the Manual (to which Azpilcueta himself refers in the dedication to the reader of the $155^{2}$ edition), see Silva, "A primeira suma portuguesa de teologia moral e sua relação com o «Manual» de Navarro", 371-373.

$7^{6}$ On the importance of the $8^{\circ}$ format for the definition of the readership in the 16th century, see Infantes, Del libro áureo, 137-145. See also McKenzie, Bibliography and the Sociology of Texts.

77 MC1556. On Andrea de Portonaris see Ruiz Fidalgo, La imprenta en Salamanca (15011600 ), vol. 1/3, 65-73.

78 Azpilcueta mentions Antonio da Zurara's help in the preface to the reader of the 1556 edition, and also refers to it in the preface of the 1573 Latin edition. In the Latin text, the name of the Franciscan friar changes into Joannes, and Azpilcueta adds that he was asked to make the 1556 revision by Philip II, through the Council of Castile. See Al pio lector, el Doctor Martín de Azpilcueta Navarro, Salud. en. N. s. Iesu Christo, MC1556; Candido, pioque Lectori, EC1573.

79 Polónia, "Recepção do Concilio de Trento em Portugal"; Marcocci, I custodi dell'ortodossia, 159 . 
in the Portuguese participation in the Council began even earlier and dates back at least to 1545, when he was consulted by João III in occasion of the first convocation of the Council. ${ }^{80}$ Azpilcueta's profound knowledge of the decrees of the Council (largely and publicly recognized) would appear clearly, once the Council was closed, in the parascer Azpilcueta gave to Philip II, on the interpretation of the decree on the episcopal jurisdiction on the cathedral chapters. ${ }^{81}$

In 156o, Azpilcueta also supervised a Portuguese translation of the 1556 text, including the comentarios and the reportorio, and in 1570 , there was an important update to the Manual, with a 28th chapter (capitulo veynte y ocho), printed in the kingdoms of Castile (Valladolid) and Aragón (Zaragoza) and later in Portugal, which already contained all the references to the Council of Trent to be integrated in each of the 27 chapters of the Manual. ${ }^{82}$ All the previous modifications would be condensed in the 1573 Latin edition, printed in Rome by Vittorio Eliano in which a more theoretical section, organised in 10 preludia, was included. ${ }^{83}$ Latin became the final language, preserved also in the last revision, printed in $1584{ }^{84}$

These modifications, which transformed the Manual into a big, complex and erudite book, led to the need for the numerous Compendia, which appeared form 1567 onwards and on which we will come back later. ${ }^{85}$ They sometimes also reveal the interest in comparing the different versions of the text. That is particularly clear if we look at a manuscript compendium, today preserved at least in two almost identical copies: one at the University Library of Coimbra and the other one in Rome, at the Casanatense Library. ${ }^{86}$ As we can see from the title, these two manuscripts contain notes on Azpilcueta's Manual (the Coimbra manuscript shows the title "Aliqua adnotata in Manuale Navarri",87 while the title of the Roman one is "Annotationes quaedam circa D. Nauarri

\footnotetext{
8o Brandão (ed.), Actas dos Conselhos da Universidade de 1505 a 1537, vol. 1, 144.

81 Azpilcueta, "Parescer del Doctor Nauarro".

82 MC156o; CR156o; MC1570; $\mathrm{C}_{2} 81570$.

83 EC1573. Vittorio Eliano, nephew of Elia Levita, converted in Venice in the 1540 os and was a censor of Jewish books and printers; see Casetti Brach, "Eliano, Vittorio".

$84 \quad \mathrm{EC}_{15} 84$.

85 On the printed compendia of the manual, see Dunoyer, L'Enchiridion Confessariorum' de Navarro, 100-108. On the importance of the Compendia in Ibero-America see Muguruza Roca, "Del confesionario ibérico de la Contrarreforma a los manuales para confesores en la América colonial".

86 UСвG, Ms. 1173, cc. 1r-65r, referenced in Catálogo de Manuscritos, 162; BC, Ms. 740, cc. $3^{\mathrm{r}-2 \mathrm{O}} \mathrm{r}$.

87 UСвG, Ms. 1173 , c. 1 r.
} 
manuale"). ${ }^{88}$ Actually, it compares the Spanish and the Latin versions of the Manual. Pointing at specific questions discussed in the Manual, by precisely referring to passages of the texts via the marginal numbers which marked each paragraph in every chapter, these notes mainly registered the similarities between the two versions: expressions like "tam in manuali latino quam in vulgari $[\ldots]$ ";; "in utroque manuali $[\ldots]$ "..90 open the major part of them. But they also show the awareness of the differences between these two versions (underlining, for example, when something was added in the last version, "in manuali latino").91

\subsection{Finding Devices}

These multiple transformations of the text went hand in hand with the inclusion of some typographical tools, to which it is important to pay attention. These tools, some of which could be described as "finding devices", 92 show us the pragmatic nature of the book, which was meant for practical use by readers.

One of these typographical signs appears already in the 1549 edition. Here the letter "M" stood as an abbreviation for the words "mortal" or "mortally", related to the classification of sins. It was probably an ingenious way the printer adopted for saving space (and money). But it could also have been a way to visualise quickly on the page which behaviour implied a mortal sin.

Beginning with the $155^{2}$ edition, many daggers " $\dagger$ " began to appear in the text. It was a typographical sign with different meanings and, since Azpilcueta does not explain it, as he does in other cases, at the present state of research it is difficult to ascertain the meaning he intended to give it in the Manual. According to the Orthographia da lingoa portuguesa, by Duarte Nunez do Lião (1576), this sign was often used to indicate that the section between daggers was not found in the original text. ${ }^{93}$ But it was more likely a device connected to the way in which the books were meant to be read and the information found in the text. These daggers seem to be part of a system of signs, which included marginal numbers and was connected to the table of contents. On the

\footnotetext{
88 BC, Ms. 740, c. 3 r.

89 UCBG, Ms. 1173 , c. 1 v.

9 UСBG, Ms. 1173 , c. 2 r.

91 UCBG, Ms. 1173, c. 9r. A similar awareness of the differences between the Spanish and the Latin editions is also present in Francisco de Gouvea's (1540-1628) more critical Antinavarrus; see Gouvea, “'Antinavarrus' .

92 On early modern finding devices, see Blair, Too Much to Know, 132-16o.

93 Leão, Orthographia da lingoa portuguesa, obra util et necessaria assi pera bem escrever a lingoa Hespanhol, como a Latina, \& quaesquer outras que da Latina tem origen, 78.
} 
one hand, the reader could locate in the page the exact place of an argument found in the table of content, which referred to the chapter and to the marginal number: the dagger, placed on the corresponding line, indicated the very place in which this argument started. On the other hand, following the daggers on the page, the reader was able to find the exact point at which the argument started and could maybe jump from one dagger to another in order to follow the main arguments of the reasoning. ${ }^{94}$

But from the point of view of the typographical tools, the 1556 edition is probably the most interesting one. In this edition, the asterisk “*” appears and is used for showing the updated parts of the edition, both in the texts and in the notes, making these changes visible to the reader. ${ }^{95}$ That was apparently a common use at that time. The 1536 edition of Nebrija's Castillian-Latin Dictionarium, made by his sons, showcased the same device: new entries were marked with an asterisk, thus making the lexical additions immediately visible to the potential buyers. ${ }^{96}$ Moreover, from 1556 onward, an extensive Repertorium would be added, in which, under the label "Mandamiento", the author listed, in a few pages, all those conducts, which would imply mortal sins against the Decalogue and the Commandments of the Church. ${ }^{97}$ As we can read in the "aviso", which closes the dedication to the reader, this part was expressly addressed to both the penitents, who desired a very small tool to quickly remember all their sins, and the confessors, who needed a small practical memory for the examination of the penitent. ${ }^{98}$

94 I would like to thank Alexander Wilkinson and Christiane Birr for their precious help in finding a possible use of daggers.

95 The use of the letter M., as well as of the asterisks is clearly explained in the Aviso, which ends the dedication to the reader of the 1556 edition. Martín de Azpilcueta, Al pio Lector, el Doctor Martín de Azpilcueta, Navarro, Salud. En N.S. Iesu Christo, in MC1556. According to the 16 th century Portuguese gramatica, the asterisk was used to show that some words or verses were missing in a text. Leão, Orthographia da lingoa portuguesa, obra util et necessaria assi pera bem escrever a lingoa Hespanhol, como a Latina, \& quaesquer outras que da Latina tem origen, 78 .

96 Ellsworth Hamann, The Translations of Nebrija, 25.

97 Reportorio general y muy copioso del Manual de Confessores, y de los cinco Comentarios para su descalacion compuesto, Salamanca, Andrea de Portonariis, $155^{6}$ (CR1556), cc3r-cc5v.

98 Martín de Azpilcueta, Al pio Lector, el Doctor Martín de Azpilcueta, Navarro, Salud. En N.S. Iesu Christo, in MC1556: "Al desseo de los penitentes, que desseavan una muy breue memoria para acordarse de todos sus pecados muy presto, se satisfaze en el reportorio con aver puesto muy brevemente en la palabra mandamiento todas las maneras comunes de pecar contra el mãndamiẽto de amar a Dios, y el de amar al proximo, y los otros diez del Decalogo, y los cinco dela yglesia, por su ordẽ, y en cada palabra de cada pecado mortal, y aun de cada otro pecado las maneras comunes de caer en cada uno dellos. Por lo 
So, we can assume that particularly this edition of the Manual was addressed to different kinds of readers. Also, the use of the marginal notes can contribute towards our understanding in that regard. While in the 1549 edition the not so frequent doctrinal references were embedded in the text (and it will be the same for the Latin edition), the $155^{2}$ and the 1556 edition showcased an important apparatus of marginal notes, written in Latin. The learned information and use of Latin for the erudite apparatus of notes (which generally referred to Latin works and was characterised by the complex system of abbreviations with which only erudite people were familiar with) suggests that they were clearly written for learned people, while the rest of the text could be understood by simple penitents and confessors.

\subsection{A Linguistic Travel towards Universality?}

But let us return to the linguistic journey of the text, directly connected to Azpilcueta's own travels from Portugal, to Spain and finally to Rome; what would it mean to move from vernacular to Latin in the second half of the 16th century?

The choice of vernacular was a general trend for the literature for confessors in the 16th century, which tried to satisfy the urgent need for education of confessors, providing all the instruments they needed to fulfil their tasks properly. ${ }^{99}$ Azpilcueta's Manual, too, at least at the beginning of the story, was probably meant to satisfy this need, in the framework of the religious reformation sought by Dom Henrique in Portugal. That was probably also the reason, which stood behind the Castilian edition, requested by the king of Spain via the Council of Castile, which, on the other hand, as we saw, became more complex and erudite. Here the choice of vernacular language probably accompanied the early awareness of its "Imperial face", following Antonio Nebrija's statement that "language was always the companion of empire". ${ }^{100}$

qual mesmo se ha satisfecho tambien alos cõfessores, que desseavan un memorial breve, para pregũtar de todos los pecados con la alegacion del lugar del Manual, donde podran ver si, o quãdo es mortal, o venial: o ni mortal, ni venial. Y asi enel Manual, como enel Reportorio M. significa mortal, o mortalmente".

99 On the large opening to vernacular for the literature for confessors, which marked mainly the second half of the 16 th century, see Turrini, La coscienza e le leggi, 113. The choice of vernacular for religious education, both of believers and priests was confirmed by the Council of Trent. While Latin still remained the official language of the Church, vernacular was the language chosen for religious education. Concilium Tridentinum, Sessio XXIv (11 Novembris 1563), Decretum De Reformatione, can. VII, in Conciliorum Oecumenicorum Generaliumque Decreta. The Oecumenical Councils of the Roman Catholic Church. From Trent to Vatican II, vol. 3, eds. Ganzer, Alberigo and Melloni, 136-137. 
The final move to Latin, back to the language of the Church, theology and law, suggests perhaps a new and more universal aim of the Manual, and also a further shift of the target reader. ${ }^{101}$ In his preface to the reader, Azpilcueta, being more than eighty years of age, lists several reasons that pushed him into making the big effort of translating his Manual into Latin. First of all, he did not do it for glory but in order to better serve the entire Respublica Christiana. Many excellent men from both Spain and Italy had asked him for the Latin translation of his Manual and a Latin version so juicy and brief ("tam succiplenae tamque affectatae brevitatis"). Providing the solution of many difficult cases concerning theology, canon and civil law required not only to perfectly know both Latin and Spanish but also a comprehensive knowledge of the three mentioned disciplines which only a few people could reach before old age. Another reason was related to some bad translations into Italian and Latin, which damaged his name, as well as the entire res christiana. But the main reason was that Latin was clearer ("clarius verbis") and more suitable for judgment (aptius sententiis), and more solid in reasoning ("firmior rationibus") than Spanish. That was even more so for the ten praeludia as well as the last updates on penance concerning the Council of Trent which had to be written in Latin in order to preserve the purity of the language ("sermonis castitate"). So, for Azpilcueta, Latin allowed expressing the concepts of law and theology more clearly than Spanish. ${ }^{102}$ But it was also more widespread ("communius") than Spanish. The choice of Latin was perhaps also related to the universal aim of the book (conceived to better serve the entire Respublica Christiana), and might have corresponded to a further shift of the target reader. We can imagine that while the vernacular Manual was mainly addressed to the confessors of the Portuguese and Spanish empires, the Latin Enchiridion was written for the erudite people of the entire world.

Such a change in the aims and target readership went hand in hand with Azpilcueta's new role in Rome as a consultor of the Apostolic Penitentiary. This dicastery of the Roman curia, recently reformed by Pius v and Charles Borromeo, administered the sacrament of penance for those particular cases reserved to the Pope as head of the Universal Church. In 1569, Doctor Navarrus

101 On the use of Latin in the early modern period, see Waquet, Latin or the Empire of a Sign. On translations from vernacular into Latin in the Renaissance see Burke, "Translations into Latin in early modern Europe"; Fery-Hue (ed.), Traduire de vernaculaire en latin au Moyen Âge et à la Renaissance.

102 EC1573, Candido pioque lectori. On the 16th century debates on the use of Latin for theological and spiritual texts, see Fragnito, La Bibbia al rogo. For the Spanish context, see Andrés, La teología española en el siglo XVI, vol. 2, 570-576. 
was appointed jurist of the court ${ }^{103}$; the Latin edition of the Manual, which appeared in 1573, right after the reformation of the Penitentiary was completed, became an important tool used by Azpilcueta in his consulting activity. If we look at the posthumously printed consilia, which were mainly the fruit of his work in that court, the Manual is constantly quoted. But his work as a consultor also contributed to updating the last revision of the Manual. ${ }^{104}$

In sum, the small 1549 book, conceived for daily use by confessors and penitents, became - with the Latin edition - the canonist's instrument of work. In this long journey from Portugal to Spain and Papal Rome, Azpilcueta made the book, originally written by an anonymous Franciscan friar, more and more his own work. We can assume that he made this process of appropriation visible by inserting his coat of arms (a parted quarterly shield, with a reversed crescent in the $1^{\circ}$ and $4^{\circ}$ quarters, and the $2^{\circ}$ and $3^{\circ}$ chequered quarters) on the front-page of the 1573 edition. ${ }^{105}$

\section{Processes of Epitomisation: Condensing and Updating Legal Knowledge ${ }^{106}$}

But which kind of knowledge was condensed in the Manual? Looking once again at the different editions, we can detect a double process, directly related, on the one hand, to the need for a small and portable text, and, on the other hand, to the importance for confessors to manage an extensive and updated amount of knowledge, which could help in resolving all the concrete and new cases of conscience a confessor might have to deal with.

First of all, we can perceive what we could call a "top-down" process of selection, condensation and reorganisation of learned normative knowledge, in a

103 Borromeo, "Il concilio di Trento e la Riforma postridentina della penitenzeria apostolica $(1562-1572) ", 131$.

104 Azpilcueta, Consiliorum seu Responsorum, lib. I, De Iis quae, cons., n. IX, 217-220: $219 \mathrm{~B}$. "ut singulariter declaravit Caiet. super 22 S. Tho. q. 189 art 5 quem piget non allegasse in Manual. Confes. hactenus edito ubi tamen citabitur Deo annuente in proxima aeditione". The handwritten Consilium is preserved at the Vatican Archive: ASv, A.A. Arm. I-XVIII, 3129 , cc. $1 \mathrm{r}-7 \mathrm{v}: 5 \mathrm{r}$.

105 The coat of arm is explicitly attributed to Azpilcueta in the 1584 Roman edition of the Enchiridion (EC1584). In the title page verso, in fact, the coat of arm, printed right below Azilcueta's portrait, is provided with the following caption: "Auctoris insegna gentilicia". On Azpilcueta's family coat of arm, see Atienza, Nobiliario Español, 394.

106 The analysis of the transformation process of the Manual across the editions supervised by Azpilcueta is the object of the project 'Hyperazpilcueta' at the Max Planck Institute for European Legal History: https://www.rg.mpg.de/forschung/hyperazpilcueta. 
brief book and in a systematic way, to concretely adapt it for use in confession. But along with brevity, the other requirement of the Manual was to provide updated knowledge about conscience. The way in which Azpilcueta reached this goal was by significantly transforming the text from one edition to another. As said before, not only did Doctor Navarrus added progressively more and more references to the Council of Trent - the first sessions of which were coeval to the first editions of the Manual. But he also integrated the Manual, with more and more solutions to cases of conscience as well as answers to urgent political and religious questions, coming from the global political contexts, in which the different transformations of the Manual were conceived. This can be understood as a "bottom-up" process, related to concrete questions Azpilcueta was asked from correspondents from both the Old and the New World.

It is hard to say if these processes of condensing legal knowledge and updating it with answers to those concrete questions marked Azpilcueta's specific contribution to the literature for confessors of the time. But it is probably fairly to say that what distinguished Azpilcueta's Manual from other Manuals for confessors, at least from those printed under the initiative of the Portuguese Crown in the same years, was the crucial role he attributed to canon law and civil law which he condensed and somehow injected into 'Rodrigo do Porto"s text.

Of course, the need for condensing learned doctrinal knowledge in a brief manual was quite common, expressed particularly in the texts written by learned authors. That was the case, for instance, of the Spanish theologian Francisco de Monzón, belonging to the Dominican order, who was Azpilcueta's colleague at the University of Coimbra and the King's chaplain and preacher. Dedicating to João III his Norte de confessores (1546) - which was meant to guide confessors like a compass in the resolutions of complex cases -, he described his books as small in size ("pequeño en el volumen") but very condensed in sentences ("muy compendioso en las sentencias") because it contained the flowers of the doctrine written by the sacred doctors in theology and canon law ("porque contiene las flores de la doctrina que a este proposito escriueron los sagrados doctores teologos y canonistas"). ${ }^{107}$ But in the case of Azpilcueta's Manual we can see something more.

In the preface to the reader of the 1549 edition, in which Azpilcueta largely testified the conformity of the content of 'Rodrigo do Porto"s work with Christian doctrine, we can read what specifically distinguished the text he was publishing from the other manuals that Doctor Navarrus could have seen in his over twenty years of teaching experience on canon law, not only in Portugal

107 Prologo endereçado al mui alto y muy poderoso Rey nuestro segnor don Juan tercero deste nombre, in Monzón, Norte de confessores. On Francisco de Monzón and his works see Fernandes, "Francisco de Monzón". 
but also in Salamanca and Toulouse. In his opinion, there was no book (with the exception, of course, of the canon law books), neither in Latin nor in vernacular (Portuguese, Castilian or French), which was so "useful and safe" as this book. ${ }^{108}$ In fact, some authors of those books spoke unclearly, or in general, without going down to the particular, while others went too much into particular cases, thus becoming obscure for the common knowledge of confessors and penitents. ${ }^{109}$ Some of them spoke like "pretores", without referring to reasons, texts or authorities, hoping that their dicta had the force of law.110 While some authors followed false opinions, others did not offer any reference at all - often in order to avoid quoting the "modernos", especially in those texts in which they argued better than the ancients. On the contrary, 'Rodrigo', or, better, the anonymous author of the manual that Azpilcueta was introducing, treated clearly and briefly both the general and the particular cases. Azpilcueta stressed that the author had previously discussed with erudite men and experienced confessors of his Order about all the doubts related to what had been written on penance, both by canonists and theologians, in order to choose the most truthful opinions. And in order to justly give to each one his own, he quoted ("allega") even the most contemporary authors ("aun de los modernissimos") - and amongst them, also Doctor Navarrus himself. According to this preface, 'Rodrigo' did not include offensive references, nor did he silence someone because he belonged to another order or religion, but, with the only desire of serving God, he searched for the truth - and found it - with the simplicity characteristic of the Provincia da Piedade. ${ }^{111}$

108 MC1549, El doctor Martín de Azpilcueta Nauarro al lector: "a mi iuyzo muchos años ha, que ninguna obra de su tamaño se imprimio, ni en latin, ni en romance Portogues, Castellano, ni Frances tan prouechosa, y segura para los confessores y penitentes como esta, sacados los textos de canones".

109 MC1549, El doctor Martín de Azpilcueta Nauarro al lector: "algunos hablan confuso, o en general, sin descender a lo particular, o bien poco. Otros descienden mas: pero por tan luengos y obscuros grados, y escalones de disputationes, que el commun saber de los confessores y penitentes, no los puede andar".

110 MC1549, El doctor Martín de Azpilcueta Nauarro al lector: "Dellos hablan como pretores, sin razon, texto, ni otro autor, queriendo que sus dichos tengan fuerca de editos".

111 MC1549, El doctor Martín de Azpilcueta Nauarro al lector: "El autor empero desta como prudente con gran cordura igual iuyzio \& diligencia, todo lo general, y particular ha tocado [...] Y de todos los que en su materia han escripto: assi Canonistas como Theologos, y mixtos, comunicadas las exquisitas dubdas, con muy doctos varones, y muy experimentados confessores, quales los ay cierto en su orden, ha trabaiado de escoger las mas verdaderas opiniones. Y por dar a cada uno lo suyo, como iusto, los lugares aun de los modernissimos, allega sin retener nada delo ageno: como amador de la muy alta pobreza, que professo y guarda. A nadie allega para lo afrentar. A nadie calla por ser de orden, o religion diuersa. Antes con solo amor y desseo de seruir a IESv CHristo, busca y toma la verdad de doquier que se halla: sin ningun sabor de rancor, faction o parcialidad, 
As this attitude towards doctrinal allegations was the distinctive character of the first version of the text, by studying the preface to the reader of the $155^{2}$ edition we can observe the nature of the intellectual exercise of epitomising learned legal knowledge that both Azpilcueta and 'Rodrigo', in collaboration, performed on the text.

\subsection{An Effort That Almost Killed Him. Azpilcueta's Words on Epitomisation}

In Azpilcueta's preface to the reader of the $155^{2}$ edition, we can read in his own words what I called the "top-down" process. He explains the intellectual processes related to the reformation of the 1549 edition of the Manual which he carried out in continuous collaboration with the anonymous author of the first version of the text. It comprised, first of all, selecting (he uses the expression manojo de flores, bunch of flowers, which directly recalls the legal tradition of flores legum) and translating the learned legal knowledge, expressed in Latin, related to his university teaching experience, into a practical manual in vernacular language. We might think about translation here not only in a literal sense; what was at stake was probably a process of adapting learned canon law knowledge to the everyday practice of confessors.

Azpilcueta refers to the great weight and technical complexity of his task, in reforming the 1549 edition, which consisted not only in acknowledging others' opinions in the difficult matters of cases in theology, canon and civil law, but also in articulating these opinions and explaining them very briefly. Moreover, when the available arguments were insufficient, it was necessary to find and offer new ones. He explains that the help of God made him overcome the spiritual anguish and physical suffering, which was related to the great doubts and the fear of erring in his resolutions, as well as to the concern that he could not leave the resolutions of these doubts to the simple confessors. ${ }^{112}$ For preserving

sin ningun olor de vanidad, inuidia y ambicion, con muchos perfumes de charidad, y prudentissima simplicidad: dignos de las boticas de los padres exemplares dela prouincia dela piedad".

$112 \mathrm{MC} 1552$, Al pio Lector, el doctor Martín de Azpilcueta Navarro: "quanto es la [obra] de no solamente referir, los paresceres agenos en infinitas, difficiles, y altas materias de casos quotidianos de las tres soberanas facultades, Theologia, Canones, y Leyes, de tanto peso quanto es dezir si es o no peccado. M. si ay censura o irregularidad, o necessidad de restituir. Pero aun affirmarlos y brevissimamente por la mejor razon, texto, glosa, o authoridad especial, y ciertamente allegada, fundarlos, y hallar y probar nuevos, quando los hallados no bastavan: como con la ayuda de Dios lo hemos hecho o por mejor hemos sido su instrumento a que ha dado esfuerço para suffrir muchas angustias de animo y trassudores del cuerpo, causadas por las grandes dubdas, y ygual temor de errar enla determinacion 
and increasing his authority, it would probably have been better (and easier) to have cleaned and revised some material on the Decretum and Decretals, written in Latin (the most common language), which he had already prepared for his courses and which was largely demanded by his audience. On the contrary, he decided to write the Manual in Portuguese and Spanish, therefore doubling his works and writing in two languages "that did not cross the Pyrenees" (but actually crossed the Atlantic!). ${ }^{113}$

So, writing briefly and in vernacular languages what could be more easily expressed in Latin after revising canon law materials already prepared, was an effort that almost killed Azpilcueta ("esto ha sido matarnos"). The Manu$a l$, in fact, looked simple, because of the extreme brevity required, but it was, indeed, the fruit of very intense efforts. According to Doctor Navarrus, certain half-pages demanded of him the same work and study needed for preparing an entire repetitio (which was an academic exercise that usually took days to prepare), and other pages required the same study and work as many good lessons at the most important chair in canon law. Azpilcueta conceded that by looking at those pages written in a vernacular language, and in such a brief and clear manner, one would not surmise that it took so many hours of study. But he insisted that it would not have been possible to accomplish this "pious work" if he had not been so experienced, namely if he had not taught for more than twelve years on matters of theology, civil law, and canon law, from which he took the mentioned decisions. Some of them were offered to the public for the first time in the Manual, after the author had been asked "by many excellent confessors of this and other kingdoms". 114

dellas: y por veer que no convenia a esta edad y opinion de letras remetirla al simple confessor".

$113 \mathrm{MC} 155^{2}$, Al pio Lector, el doctor Martín de Azpilcueta Navarro: "y aun porque nos paresciera mas conveniente para la conservacion y augmento de nuestra authoridad (la qual para mas servir a Dios, se deve procurar por las personas publicas) sacar en limpio, con la mitad de trabajo, y estudio, lo que sobre muchas partes del Decreto y Decretales años ha, tenemos en Latin (comun lengua de la mayor parte de Europa) escritos y prometidos a nuestros oyentes, y a otros muchos: y por falta de tiempo para los perfectionar retenidos, que con doblando trabajo y tiempo ocuparnos en hazer esto en romance Portugues y Castellano, que no passa los montes Pyreneos".

$114 \mathrm{MC} 155_{2}$, Al pio Lector, el doctor Martín de Azpilcueta Navarro: "Ca en verdad algunas medias paginas ay en esta reformacion, que se ha compuesto con estudio bastante para una repeticion: y muy muchas con bastante para dos, tres, y quatro liciones de prima buenas aun que, por veer las en romance, y tan breve y claras, no os parecera que llevan sendas horas de estudio: y aun os certificamos que no nos bastara esto, diez annos antes, ni aun agora si Dios para tan pio negocio, no proveryera, en que nos hallassemos tan curtidos, con tan vehementes, y continuas liciones, repeticiones, disputaciones, y resoluciones dictadas, y escrita estos diez, o doze años en las materias dela dichas tres facultades, de 
Although Azpilcueta's prose was probably following the topos of the jurist overwhelmed by his endeavour, this passage reveals the importance of his teaching experience as a fundamental component of the Manual, as well as the difficulty of this process of condensing learned legal knowledge into a brief, clear and vernacular text, which also provided new solutions to new problems. Moreover, as I said, Azpilcueta dedicated many learned books to the topics discussed in the Manual, and these works, together with many other sources, are constantly quoted in it. The preface, in fact, also makes a reference to Pliny the Elder's opinion about the importance of acknowledging all the sources that were of help to an author. ${ }^{115}$ Giving evidence of their statements was, of course, a common practice among jurists. At the same time it can be considered as the other side of epitomisation: providing access to an entire library of selected books on conscience.

\subsection{From the University Comentarios to a Practical Manual. Epitomisation in Action}

This process of selection, condensation and translation of learned knowledge in the Manual can be demonstrated with regard to one of the most famous of Azpilcueta's learned works, which was related to his teaching experience in Salamanca and Coimbra: his commentary to the section of Gratian's Decretum dedicated to penance, the last part of which (the comment on the 5th, 6th,

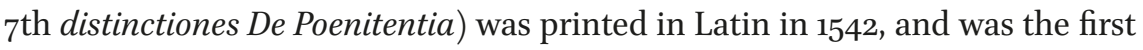
of Azpilcueta's books to be printed. ${ }^{116}$ One of the initial sections of this commentary is dedicated to the fundamental topic of the circumstances of sins, to which confessors paid more and more attention because of their relevance for determining the penance, asking the penitent to clearly describe these circumstances. I am referring to Azpilcueta's commentary to the chapter consid-

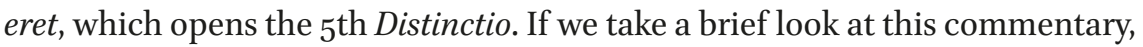
comparing it with chapter 6 of the Manual, explicitly dedicated to the circumstances of sin, we can gain a first impression into the way in which Azpilcueta transformed and condensed learned legal knowledge. ${ }^{117}$

donde se avian de coger las sobredichas determinaciones: alguna delas quales nunca hasta agora osamos dar siendo importunados por palabra y cartas de muchos excellentes confessores destos y otros reinos".

115 MC1556, Al Pio Lector, el Doctor Martín de Azpilcueta Nauarro, Salud. en N.S. Iesu Christo; EC1573, Candido Pioque Lectori. On Pliny's model of organization of knowledge, see Blair, Too Much to Know, 18.

116 On the connections between Azpilcueta's Commentary and the Manual, see Lavenia, L'infamia o il perdono, 233.

117 For exploring the transformation process of chapter 6 of the Manual accross the editions analyzed, I made use of the digital tool LERA: https://lera.uzi.uni-halle.de/?lang=en. 
Let us begin with the 1549 edition. The chapter opens saying that the confessor had to expressly ask the penitent for the circumstances that he necessarily had to confess. The text focuses particularly on those aggravating circumstances which transformed a sin into another one, thus modifying the nature of the sin (e.g., committing theft in a sacred place became sacrilege); or those circumstances, which mortally aggravated a sin, meaning a venial sin became a mortal one. ${ }^{118}$ Alleviating circumstances are also mentioned later in the chapter but did not necessarily have to be confessed, as well as those aggravating circumstances which recast a small sin as a big (but not a mortal) one.

The same schema is reproduced in the $155^{2}$ edition, but here Azpilcueta added something and reorganised the text. Starting from the $155^{2}$ edition onwards, Azpilcueta clearly augmented 'Rodrigo do Porto"s text with legal knowledge, then further enriching his legal discourse in the following 1553 and 1556 Spanish editions, as well as in the 1573 Latin edition. In particular Doctor Navarrus translated, condensed and "injected" in the chapter, what he largely developed in the already mentioned commentary to the chapter consideret. ${ }^{119}$

First of all, the connection between chapter 6 and Azpilcueta's commentary on chapter consideret is clear at first glance if we look at the marginal notes. In fact, in chapter 6 of the Manual, Azpilcueta constantly refers to his commentary; one-third of the marginal notes recall explicitly Azpilcueta's commentary to the chapter Consideret, using expressions like "as we demonstrated elsewhere" ("segundo que ho declaramos em outra parte"; "como aly ho dissemos"). ${ }^{120}$

Epitomisation implied, first of all, a process of selection and translation, from Latin to vernacular. What Azpilcueta added to "Rodrigo"s chapter was the legal definition of the circumstances of sins, which is totally lacking in the first 1549 version and which is condensed in the two first paragraphs of chapter 6, added in the $155^{2}$ edition.

Let us look at these first two paragraphs of chapter 6 of the Manual, comparing it with the Commentary, starting with the comparison of the summaries (for the summary of the Manual we consult the 1556 edition, where the summaries first appear). "Circumstantia quid", which opens the list in the Commentary, becomes "Circunstancia que es?" in the 1556 Manual. This first point is followed, in the Manual, by the statement that there are seven kinds of circumstances "y que ay siete especies della", which recalls the fourth point of

118 MC1549, cap. 6, 23-31. On the aggravating circumstances of sin, see Tentler, Sin and Confession in the Eve of the Reformation, 116-120.

119 Azpilcueta, In tres de poenitentiae distinctiones posteriores commentarii, 27-73.

120 For instance, MC1552, cap. 6, 32 § 1 , 2 . 
the Latin summary "circumstantiae septem \& quare tot". ${ }^{21}$ The Spanish summaries are translated into Latin for the 1573 editions, in which we read "Circunstantia quid nu. 1 \& septem eius species". 122

Chapter 6 of the $155^{2}$ edition begins, in fact, with the definition of "circumstance of sin", translating into vernacular (firstly into Portuguese, then into Spanish) the same definition offered in the commentary: "a circumstancia do peccado, segundo a mente de S. Tho[mas] \& outros, he hum accidente daquilo, que he peccado",123 (coming from "circumstantia peccati accidens quoddam ipsius erit peccati"). ${ }^{124}$ In a marginal note, together with Aquinas, Azpilcueta recalls also the other authors (S. Antoninus of Florence and Jean Gerson) on which he based his commentary to chapter consideret, which is expressly quoted in the Manual. ${ }^{125}$ The same definition is preserved in the Spanish editions $(1553,1556)$. But by rethinking the text in another language, moving from Portuguese to Spanish, interestingly Azpilcueta makes a little shift: before mentioning the interpretes, expressly quoted in the marginal note together with his commentary, he refers to Gratian himself, namely to the chapter consideret, stressing that the given definition was, first of all, a legal one: "la circunstancia del pecado, según la mente del derecho y de sus interpretes es un accidente de aquello, que es pecado". 126

The second paragraph that Azpilcueta adds in the $155^{2}$ edition is dedicated to the different types of circumstances of sin, taking them, once again, from his commentary to chapter consideret. Both in the Manual and in his commentary, Azpilcueta chose the ones proposed by Thomas Aquinas, who enumerated them, as it was usual in the summae confessorum recurring to the mnemonic known from Cicero's Rhetoric: "Quis, quid, ubi, quibus auxiliis, cur, quomodo, quando" (who, what, where, by what help, why, how, when). ${ }^{127}$ In both texts Doctor Navarrus expressed his preference for this classification instead of the

121 MC1556, cap. 6, 30-31. Azpilcueta, In tres de poenitentiae distinctiones posteriores commentarii, $28-31$.

122 EC1573, cap. 6, 65v.

123 MC1552, cap. 6, 32 § 1.

124 Azpilcueta, In tres de poenitentiae distinctiones posteriores commentarii, 32, n. 1.

125 MC1552, cap. 6, 32 § 1 marginal note p). See Azpilcueta, In tres de poenitentiae distinctiones posteriores commentarii, 32 , princ.

126 MC1556, cap. 6, 31 § 1. Interestingly, this shift in meaning is already present in the 1553 Spanish edition, in which Azpilcueta, for the first time was rethinking the text in another language. MC1553, cap. 6, $19 \S 1$. The same definition is somehow stabilised in the Latin edition. EC1573, 66r. "Pro fundamento materia praesentis, in primis asserimus circunstantiam peccati iuxta mente iuris [...] esse quoddam accidens rei, quae peccatum est".

127 MC1552, cap. 6, $32 \S$ 2. See S. Thomae de Aquino, Summa Theologiae, Prima Secundae, q. 7 , a. 3 . 
one proposed by Pierre de la Palu, in his commentary on Petrus Lombartus' Sententiae, who also added the word "quoties", frequently, to his list. In Azpilcueta's mind, this last one was not a circumstance but simply a multiplication of the sin. Interestingly, but not surprisingly, the Manual provided not only the Latin version - which, in the Spanish 1553 and 1556 editions, was "enclosed" in a marginal note - but also the vernacular translation of the verse. ${ }^{128}$

But epitomising knowledge also implied a major stylistic modification, directly related, again, to a very attentive selection process: from the scholastic prose of university relectiones to a simple, more linear style by choosing only the solution provided for a special doctrinal question. In fact, if the commentary's reasoning is organised in the scholastic way of pro, contra and resolutio, the Manual directly provides a definition and some arguments, which are "declared" or "crumbled" - Azpilcueta uses the expression "de declara", 129 "se desmenuzara"130 - in corollaries ("ilações", "corolarios"), thus directly proposing the solution instead of showing the dynamics of the reasoning. This is the case, for example, of the explanation of his choice of the expression "de aquello (que es pecado)", instead of using directly the word "pecado", sin, in his definition of circumstances; the reason given by Azpilcueta in the Manual was that sometimes a sin could become a sin only because of the circumstances, and was not a sin by itself. This is precisely the translation of the respondeo in the first reasoning pro et contra of the commentary, located in paragraph 3: Azpilcueta does not recall the entire reasoning, but directly provides the solution of the respondeo, to which he refers in marginal note c). ${ }^{131}$

As I said, Azpilcueta also reorganised the text in a new and clearer manner. Right after the mnemonic, a paragraph follows which starts with a clear list of all and the only circumstances ("todas \& soos aquellas") that had necessarily to be confessed. Here, once again, he selected, translated and condensed what he said in his Commentary. ${ }^{132}$ Azpilcueta mentions those circumstances that transformed an action into a mortal sin, and the ones that could change the typological character of a mortal sin. By stressing the mortal nature of the sin, as a fundamental element for necessarily including the circumstances of sin in the practice of confession, Azpilcueta clarified an aspect that was not

\footnotetext{
$128 \mathrm{MC}_{1553}$, cap. 6, 20 § 2; MC1556 cap. 6, 31 § 2 .

$129 \mathrm{MC}_{1552}$, cap. 6, $33 \S 3$.

130 MC1553, cap. 6, 20 § 3 ; MC1556, cap. 6, 31 \$.

131 MC1556, cap. 6, $31 \S 1$. See Azpilcueta, In tres de poenitentiae distinctiones posteriores commentarii, $33 \S 3$.

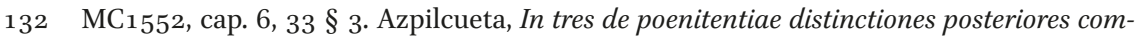
mentarii, $33-34 \S 5$.
} 
clearly defined in the 1549 edition. It is an interesting point that doctor Navarrus develops in the following transformations of the text, namely enriching the discussion and updating the text with the new canons and chapters of the Council of Trent.

\subsection{Updating and Condensing Knowledge: Azpilcueta and the Council of Trent}

Some early references to the ongoing Council are already present in the $155^{2}$ edition, namely to Session VI, of 13 January 1547, which deals with the crucial topic of justification. But the first most important updates of the text with references to the Council of Trent appeared in the 1556 edition, and were made visible by an asterisk "*”. In Chapter 6, we can easily identify this kind of addition on the page, inserted right after the paragraph listing the typologies of circumstances that had to be confessed. This is a good example of how Azpilcueta updated the text by translating and interpreting the conciliar norms, and then condensed and injected them into the text. Here Azpilcueta makes references, in particular, to Session XIV, of 24 November 1551, expressly dedicated to the sacrament of penance. He refers namely to Chapter 5 and Canon 7 , which deal with the circumstances of sin.

As is stated in the text, doctor Navarrus did not have the possibility to integrate systematically the decisions of Council in the previous editions ${ }^{\text {a* }}[\ldots]$ avisamos, que despues que esto se imprimio, declaro por herege el concilio Tridentino, al que dixere, que no somos obligados a confessar la circunstancia, que muda la especie de pecado $[\ldots]^{* \prime}$. Only after the publication of the Manual the Council condemned as heretics those who affirmed that it was not necessary to confess the circumstances that changed the type ("especie") of sin. Here Azpilcueta translated Canon $7,{ }^{133}$ also explaining the way in which this passage should be understood and interpreted. In particular he excluded the need to confess those circumstances that transformed a venal sin into another venal one: "Lo qual se ha de entender, de la circunstancia, que muda la especie de pecado venial en mortal, o la del mortal en otra mortal, y no de la que muda en otro venial, que no es necesario confessarlo". ${ }^{134}$ Dr. Navarrus, in fact, went beyond the letter of the norm, and elucidated even what the decrees as such did not say. In particular, he added a third type of circumstances to be necessarily

\footnotetext{
133 "Si quis dixerit, in sacramento poenitentiae ad remissionem peccatorum necessarium non esse iure divino, confiteri omnia et singula peccata mortalia [...] et circumstantias, quae peccati speciem mutat [...]: anathema sit". Conciliorum Oecumenicorum Decreta, ed. Istituto per le Scienze Religiose, Sess. XIV, cap. 7, 712.

134 MC1556, cap. 6, 32 (emphasis added, M.B.).
} 
confessed, not mentioned by the Council: those circumstances that made good (or non-bad) behaviour a mortal sin. ${ }^{135}$ For grounding his interpretation he referred to a passage taken from the already mentioned chapter five of Session XIV, thus somehow interpreting the Council through the words of the Council itself: the confessor, being a judge, cannot correctly judge the case of the penitent without knowing the circumstances that change the kind of sin. ${ }^{136}$

Azpilcueta refers to the conciliar norms also in the eighth "corollary" of his argumentation and the reference to the Council - this time in the marginal note - is functional to support $a$ contrario his idea that it was not necessary to confess all the aggravating circumstances but only the ones responding to the criteria mentioned above. ${ }^{137}$ In this way Azpilcueta reinforced his opinion against the theologian Marsilius of Inghen, who affirmed the need to confess also those circumstances that clearly and significantly aggravated the $\sin .{ }^{138}$

This point, in which Azpilcueta not surprisingly draws largely on his Comentario, was further developed in the section dedicated to chapter six of the $\mathrm{Ca}$ pitulo veynte y ocho (1570) and integrated, as well, in the Latin edition. ${ }^{139}$ Here doctor Navarrus adds to his eighth "corollary" a discussion with the Dominican Domingo de Soto, a crucial figure of the School of Salamanca, confessor and theologian of Charles $\mathrm{v}$ at the Council of Trent. While de Soto in his commentary of Petrus Lombardus' fourth book of Sentences (1557) takes side with Marsilius of Inghen, ${ }^{140}$ Azpilcueta does not change his position, confirmed by the Council, and his reasoning moves from the doctrinal level to the concrete difficulties of confessors and penitents, in dealing with circumstances in the everyday practice of confession. ${ }^{141}$

135 "Y aunque el concilio no expressa, sino de la que muda la especie del pecado, pero tambien (y por mas fuerte razon) se ha de entender de la que haze a la obra, que de suyo es buena, o no mala, mortal". MC1556, cap. 6, 32 (emphasis added, M.B.).

136 "Ca la razon que a ello movio al concilio, es que el confessor es juez y no podria bien sencenciar el caso del penitente, sin se le manifestar la circunstancia, que muda la especie del pecado, la qual razon milita en las tres dichas circunstancias *". Cfr. Sess. XIV, cap. 5 "Colligitur praeterea, etiam eas circumstantias in confessione explicandas esse, quae speciem peccati mutant, quod sine illis peccata ipsa nec a poenitentibus integre exponantur, nec iudicibus innotescant, et fieri nequeat, ut de gravitate criminum recte censere possint, et poenam, quam oportet, pro illis poenitentibus imponere". Conciliorum Oecumenicorum Decreta, ed. Istituto per le Scienze Religiose, Sess. XIV, cap. 5, 706.

137 MC1556, cap. 6, § 7, 33, note h.

138 Marsilii von Inghen, Quaestiones super quatuor libros sententiarum, lib. 4, q. 12, art. I, corol 4, 572 .

139 EC1573, cap. 6, § 7, 67v-68v; See C281570, 9v-10v.

140 Soto, Commentariorum, dist. 18, q. 2, art. 4, 763 .

141 C28157o, 9v-1ov; EC1573, cap. 6, § 7, 67v-68v. 


\subsection{Updating Knowledge. Questions from the New Worlds and Answers from the Old One}

The condensation of learned legal knowledge was functional, in that it intended to offer confessors the instruments for finding solutions to every concrete case of conscience. Sometimes these cases, analysed by Doctor Navarrus in his Manual, arose from concrete questions coming from the Old and the New Worlds. That is what I called the "bottom-up" process.

First of all, as we can read in the 1556 preface to the reader, Azpilcueta was asked by Dom Henrique to answer a lot of questions and doubts ("un montón de questiones y dudas") received mainly from the Archdiocese of Evora, where the text circulated largely. The answer to these questions and doubts were integrated into the new edition, and made visible to the reader, as we have seen, recurring to the typographical sign of the asterisk “*”. But this environment, a target of Dom Henrique's reform, seems to feature also earlier: in the "Declaracion de algunos passos dubdosos" that Azpilcueta added to "Rodrigo do Porto"s text, as well as in the few special copies of the 1549 and $155^{2}$ editions of the Manual, today preserved at the National Library of Portugal and the Municipal Library of Porto mentioned before. These copies show two folders, at the end of the book, which contain answers to specific new questions concerning priests and friars. These appendices, in which the layout of the page corresponds perfectly to the layout of the editions they are bound to, are clearly related to the Manual and they constantly refer to it. Usually the author refers to specific sections with expressions like "polo acima dito", "como acima se disse" and, sometimes, they refer to other Azpilcueta's learned works saying "ou tratou ho doctissimo doutor Navarro". ${ }^{142}$

But also Jesuits, especially those in the New World, asked many questions. ${ }^{143}$ I mentioned the relation between Azpilcueta and the first Jesuits sent to Brazil, namely with Manuel da Nóbrega and Juan de Azpilcueta. With both of them Doctor Navarrus entertained an intense epistolary correspondence since the beginning of the mission. ${ }^{144}$

\footnotetext{
142 See, for example, at page $21 \S 17$ of the supplementary folder of the $155^{2}$ edition, referring to Azpilcueta's relectio In Levitico (1550) printed two years before.

143 There is a trace of the questions coming from the Brazilian missions and addressed to the Portuguese jurists and theologians, as well as of their answers in a manuscript preserved in the Public Library of Evora, which contains also the responsa on five questions given by Azpilcueta: Sententiae circa resolutionem aliquorum casuum, qui in Brasilia frequenter occurrunt, BPE, cod. CXVI/1-33 (cc. 100-16o): cc. 126r-13or. The manuscript is described by Rivara, Catalogos manuscriptos da biblioteca publica eborense, vol. 1, 16 .

144 See, for example, the letters sent to Dr. Navarro by Nóbrega (10 August 1549) in Leite (ed.), Monumenta Brasiliae, vol. 1, 132-143 and the letter addressed by Juan de Azpilcueta to the fathers in Coimbra (19 September 1553), in which he mentions his epistolary contact
} 
Especially Manuel da Nóbrega constantly sent questions to the theologians and jurists in Portugal. We know that he consulted his former professor on several topics, related to the strategies for the conversion of the indios or to specific issues connected to the marriage of converted people, ${ }^{145}$ as well as about the crucial topic of slavery, namely on the practice of selling the indios' children as slaves with their parental assent. ${ }^{146}$ If we take a look at these letters, it is possible not only to understand how important Azpilcueta's doctrines were in the New World, but also to understand how the questions raised from the Brazilian missionary context reached Portugal and were integrated into the Manual.

An example can be seen in two letters, addressed by Manuel da Nóbrega to the Jesuit Provincial, Simão Rodrigues, in late July and late August 1552, and their possible influences on the evolution of the Manual from one edition to another. ${ }^{147}$

The letters to Simão Rodrigues were directly connected to the arrival of the new Bishop in Bahia, who criticised the Jesuits' practice of confessing indigenous people through an interpreter as being a new practice never used in the church before. ${ }^{148}$ Nóbrega, replying to these critics, referred to Azpilcueta's commentary De poenitentia (1542), namely his commentary on the c. Fratres of the fifth distinctio, to support - against the Bishop - his argument for the possibility to confess this way, without prejudice to the sacrament of confession. In fact, in the afore-mentioned passage of the commentary on De Poenitentia quoted by the Jesuit, Azpilcueta said that even if confession was a secret, it was possible (but not compulsory) for the penitent who did not understand the confessor's language, to confess with the help of an interpreter. ${ }^{149}$ Nóbrega recalled the same passage of Azpilcueta's commentary also in the second letter in which he asked Rodrigues to send a list of urgent questions to the theologians

with his uncle, in Leite (ed.), Monumenta Brasiliae, vol. 2, 3-10: 10. On the relations between Azpilcueta and the Jesuits see Lavenia, "Martín de Azpilcueta (1592-1586)", 103-112.

145 Letter sent to Azpilcueta by Nóbrega (10 August 1549) in Leite (ed.), Monumenta Brasiliae, vol. 1, 141. On the point, see Castelnau-L'Estoile, "Le mariage des infidèles au XVIe siècle", 112-121.

146 See the letter by Nóbrega to Simão Rodrigues (end of July, 1552) in Leite (ed.), Monumenta Brasiliae, vol. 1, 369-375, esp. 370-371.

147 See the letters by Nóbrega to Simao Rodrigues (end of July and end of August, 1552), in Leite (ed.), Monumenta Brasiliae, vol. 1, 369-370, 407. On the point, see Cantù, La conquista spirituale, 328; Lavenia, "Martín de Azpilcueta (1592-1586)", 109-110.

148 See the letter by the Bishop Pedro Fernandes Sardinha to Simão Rodrigues (late July, 1554) in Leite (ed.), Monumenta Brasiliae, vol. 1, 357-366: 361.

149 Azpilcueta, In tres de poenitentiae distinctiones posteriores commentarii, cap. Fratres, Distinctio 5, § 85, 130-16o: 153 . 
and jurists of Coimbra. The first one was the problem of confessing with an interpreter. ${ }^{150}$

There is no trace of this topic in the 1549 edition, printed the same year, which saw the arrival of the missionaries in Brazil. But we can imagine that the Jesuits drew very early the canon lawyer's attention to this topic in their letters, or at least that the question was perceived as urgent by Azpilcueta if he felt the need to transpose into Portuguese the mentioned passage of his commentary De poenitentia, in the twenty-first chapter of his Manual (1552), dedicated to the obligation to confess once a year as a commandment of the Church. ${ }^{151}$ The topic was without any doubt amongst the most discussed ones at that time. Two years later, in fact, Doctor Navarrus would have referred to this section of his Manual, giving the same answer in one of the five handwritten consultations made to reply to some further questions coming from the Brazilian mission, today preserved at the Biblioteca Publica de Évora, one of which dealt with the topic of confessing black slaves who did not understand Portuguese. ${ }^{152}$

In the 1556 Spanish edition of the Manual, the statements on the possibility of confessing with the help of an interpreter was followed by an addition, indicated with an asterisk "**, referring especially to those who claimed that this kind of confession was entirely new and not valid (and we can perhaps find here an allusion to the position taken by the Bishop of Bahia). In fact Azpilcueta said - not only had the church always confessed in this way, but not confessing with the help of an interpreter could distance persons speaking other languages ("los de la lengua extraña") from confession. ${ }^{153}$ This statement of the importance and validity of this kind of confession was finally condensed in the Latin version of $1573 \cdot{ }^{154}$

Even a specific reference to Brazil is already present in the $155^{2}$ edition of the Manual, in Chapter 23 dedicated to the seven cardinal sins, namely to the fraud (deriving from the sin of avarice) in selling and buying. Here Azpilcueta deals with the topic of the legitimacy of buying and selling indios as slaves. Generally speaking, buying someone as a slave, while knowing that he was a free man or that he was not captured in a just war, implied a mortal sin (like in the case of black people or indios captured by Christian corsairs and sold

\footnotetext{
150 Letter by Nóbrega to Simão Rodrigues (end of August, 1552), in Leite (ed.), Monumenta Brasiliae, vol. 1, 400-409: 407.

$15^{1}$ MC1552, cap. 21, § 36, 433 .

152 BPE, cod. CXVI/1-33 (cc. 10o-16o): cc. 126r-13or: $128 \mathrm{v}-129 \mathrm{r}$.

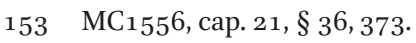

154 EC1573, cap. 21, § 36, 304v.
} 
to Christians as slaves). But this was not the case for those indios sold by their enemies as slaves, who kept them with the purpose of eating them - because life was more precious than freedom. ${ }^{155}$ Once again, Azpilcueta would have referred to this precise section of his Manual, in another of his handwritten consultations preserved in Évora dedicated to the topic of slavery in Brazil. 156

It is also likely that Juan received guidance regarding new and complicated issues from his uncle, offering Azpilcueta, in return, some important elements for writing the Manual. In his short but intense missionary activity, Juan worked tirelessly in the conversion of Brazil's indigenous people. He was not only the first Jesuit who was able to confess in an indigenous language, but he also translated the basics of the Christian doctrine into the Tupi language, recurring also to the music, dancing and typical gestures of the native people..$^{157}$

\section{6}

\section{Epilogue}

Analizing Azpilcueta's Manual, as well as its multiple transformations in the self-translation process, it is possible to identify different processes and levels of epitomisation of learned legal knowledge. Azpilcueta condensed, translated and updated in one material object, a relatively small book, the legal knowledge that confessors and penitents needed for resolving, in the concrete act of confession, new cases of conscience coming from a rapidly changing world.

Epitomising learned legal knowledge in a pragmatic manual for confessors meant, in the case of Azpilcueta, building a bridge between the world of canon law and its concrete everyday practice. This condensation of normative knowledge was always done with the aim of providing immediate solutions to the concrete and contemporary problems which concerned simple priests or Kings, the Old and the New World, the Franciscan and the Jesuit missionary

155 Cfr. MC1552, cap. 23, § 95, 565. Nóbrega had informed Azpilcueta about the anthropophagy of the indios in his first letter from Brazil. Letter sent to Azpilcueta by Nóbrega (10 August 1549) in Leite (ed.), Monumenta Brasiliae, vol. 1, 136-137. On the different ways in which native people were captured as slaves (amongst them the "resgates" concerned precisely the case of saving with slavery the indios from the anthropophagic rituals), see Abreu, "O P. Manuel da Nóbrega e a evangelização dos indígenas do Brasil", 165.

156 BPE, cod. CXVI/1-33 (cc. 10o-16o): cc. 126r-13or: 129r-129v.

157 Leite, História da Companhia de Jesus no Brasil, vol. 8, 84. Cfr. Extracto de uma carta do Padre Joao de Azpilcueta Navarro da India do Brasil, (March, 28, 1550) in Cartas Avulsas, 76. On the use of Tupi gestures and dancing, see Barros, "Notas sobre os catecismos em línguas vernáculas das colônias portuguesas (séculos XVI-XVII)", 54; Leite, História da Companhia de Jesus no Brasil, vol. 2, 299. 
experiences, the Portuguese and the Spanish empires. Doctor Navarro then collected and updated these solutions, also considering the new norms of the Council of Trent, which made his Manual into a reference work for resolving cases of conscience of the entire Respublica Christiana.

Azpilcueta's peculiar narrative on the genesis of each new edition of the text very often stressed the contingent reasons (related to the spread of the printed word that he could not fully control) that generated the need to further work on in. That held particularly true for the last transformation of the text. As we have seen, it was not only the impossibility of finding a good Latin translator for his Manual, capable of combining the truth of the doctrine with the clarity and brevity that was needed, that pushed him - an old man - to translate, improve, augment and update the Enchiridion himself. Another important factor was the existence of several bad Latin and Italian translations, printed without his consent (which often contradicted what was written in the original text and the true Christian doctrine). ${ }^{158}$

However, this was not the end of the story. If we trust the words used by Azpilcueta to address the King of Spain (and Portugal) in 1586, many people thought that the Manual, being published in Spanish, was more useful in the King's very extensive kingdoms ("en sus amplissimos Reynos de España"). For that reason they produced several compendia of the Spanish Manual without adding, improving and correcting what Azpilcueta added, improved and corrected in his last version and even saying the contrary of what was written there, but still ascribing the text to him. ${ }^{159}$ This side effect of the printing revolution - which radically reduced the possibilities for the author to control in advance the correct dissemination of his words - animated, once again, Azpilcueta's pen, compelling doctor Navarrus, aged more than ninety years, to make his own Compendio. Doing so, he finally provided the language, (Spanish) and probably also the format (a small compendium) more suitable to the needs of simple readers and big empires.

Actually, the Compendio immediately appears simpler to the reader's eyes, especially if compared to the last versions of the Manual. First of all, the text is much shorter ('only' 562 pages in quarto). It retains the structure of the Enchiridion (the ten praeludia placed at the beginning are summarised and translated into Spanish) but doctrinal references are almost completely eliminated. Some of the very few references in the text (in the form of marginal notes, albeit extremely scarce) refer to the Manual and, in this way, the Compendium

\footnotetext{
$15^{8}$ Candido Pioque lectori, EC1573; Dedication to the S[acra] C[atólica] R[eal] M[ajestad], in $\mathrm{CM}_{15} 86$.

159 SCRM, in $\mathrm{CM}_{15} 86$.
} 
appears like a tool for having access to it. The remaining references - generic, with no indication to the pertinent Session, chapters or canons - are mainly to the Council of Trent, but without any allusion to the doctrinal debates related to the canons which had characterised very much the sections added to the 1556 edition as well as the additions of Chapter 28 . In fact, they merely focus on those behaviours imposed or condemned by the Council. Also, the organisation of the text within each chapter becomes clearer. The structure of the text in the Manual that generally followed the reasoning in numbered corollaries and secondary points is substituted by a linear sequence of numbered arguments.

This becomes evident by a look at chapter 6 of the Compendio, dedicated, as said before, to the circumstances of sin. While in the Manual and in the Enchiridion this chapter is organised into three first points (the legal definition, the seven kinds of circumstances and the circumstances that have to be confessed) and eighteen corollaries (these last ones themselves subdivided into sub-arguments), the Compendio simply shows fourteen numbered arguments. ${ }^{160}$ Very interestingly, the legal definition of the circumstances of sin that Azpilcueta injected into the text from the $155^{2}$ edition onwards, disappears: the most important aspect seems to be the different kinds of circumstances, and the mnemonic (following Thomas Aquinas' version), kept only in the Spanish translation. Doctrinal references are reduced in very simple terms, and more often disappear completely. This is the case, for example, of the entire debate on the circumstances that aggravate notably, but not mortally, the sin. The ideal discussion with Marsilius of Inghen already present in the $155^{2}$ edition, as well as the interpretation of Chapter 5 and Canon 7 of Session XVI of the Council of Trent added in the 1556 edition, and the dialogue with Domingo de Soto which we find in the capitulo veynte $y$ ocho and which was later integrated into the Latin edition, are radically cut from the text. What remains is only the essential message: the fact that aggravating circumstances are not to be confessed, unless when they transform a venal sin into a mortal one, or when they change the typology of a mortal sin. ${ }^{161}$ Likewise the reasons on which Azpilcueta grounded his arguments (the omnipresent "la razon es", "porque" and "ratio est", "quoniam", or "quia" in the Spanish and Latin Manual, respectively) are very much reduced. Moreover, the original contexts of the concrete questions answered in the Manual are omitted: for example, the fact that a specific question was asked by Antonio de Zurara. With regard to the

\footnotetext{
16 o $\mathrm{CM}_{1586}, 24 \mathrm{r}$.

$161 \mathrm{CM}_{1586,24 \mathrm{~V} .}$
} 


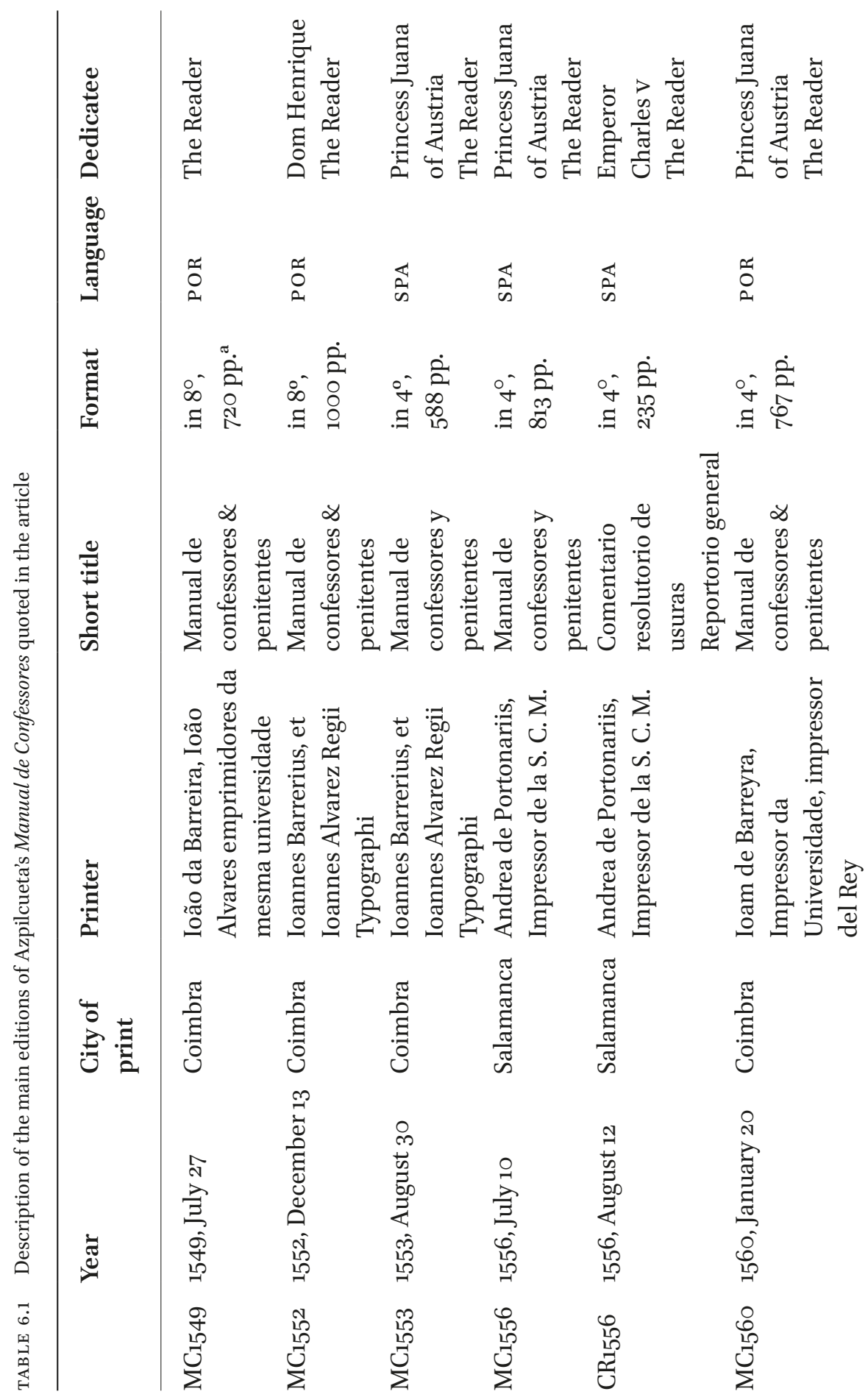




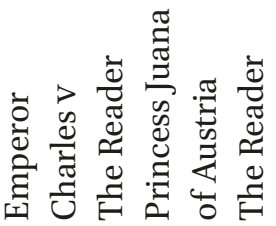

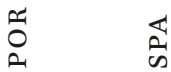

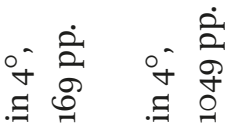
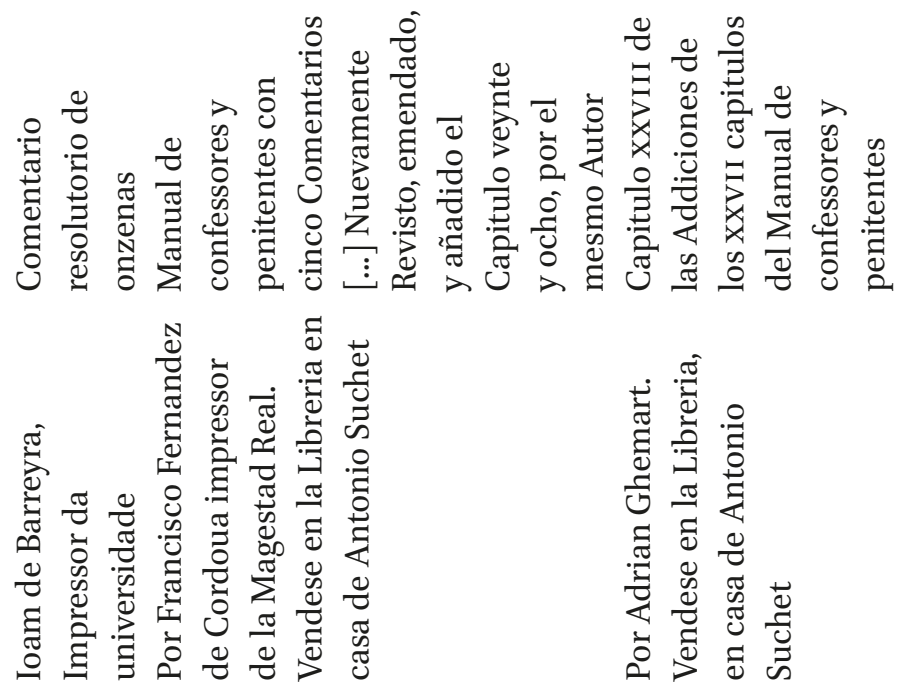

$\begin{array}{ll}\pi & \frac{7}{0} \\ \text { है } & \frac{\pi}{0} \\ 0 & \frac{\pi}{7}\end{array}$ $\underset{s}{\infty}$

$\stackrel{\dot{a}}{+\infty}$

$\Xi 9$

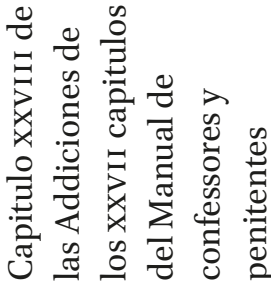

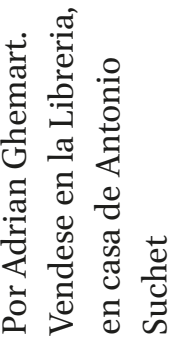

$\frac{7}{0}$
$\frac{\pi}{\pi}$
$\frac{\pi}{\pi}$
$\frac{\pi}{7}$

옹

怘 


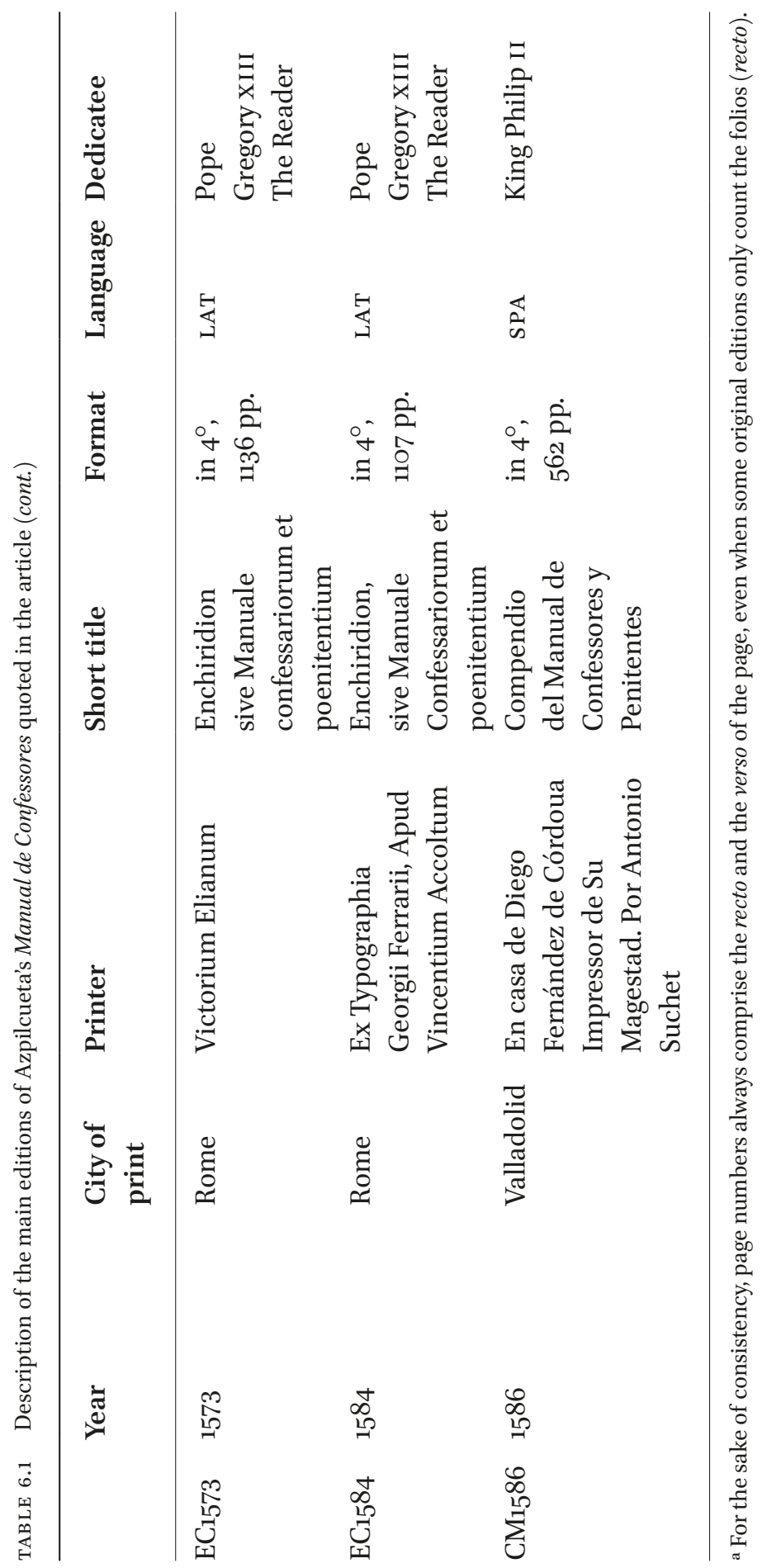




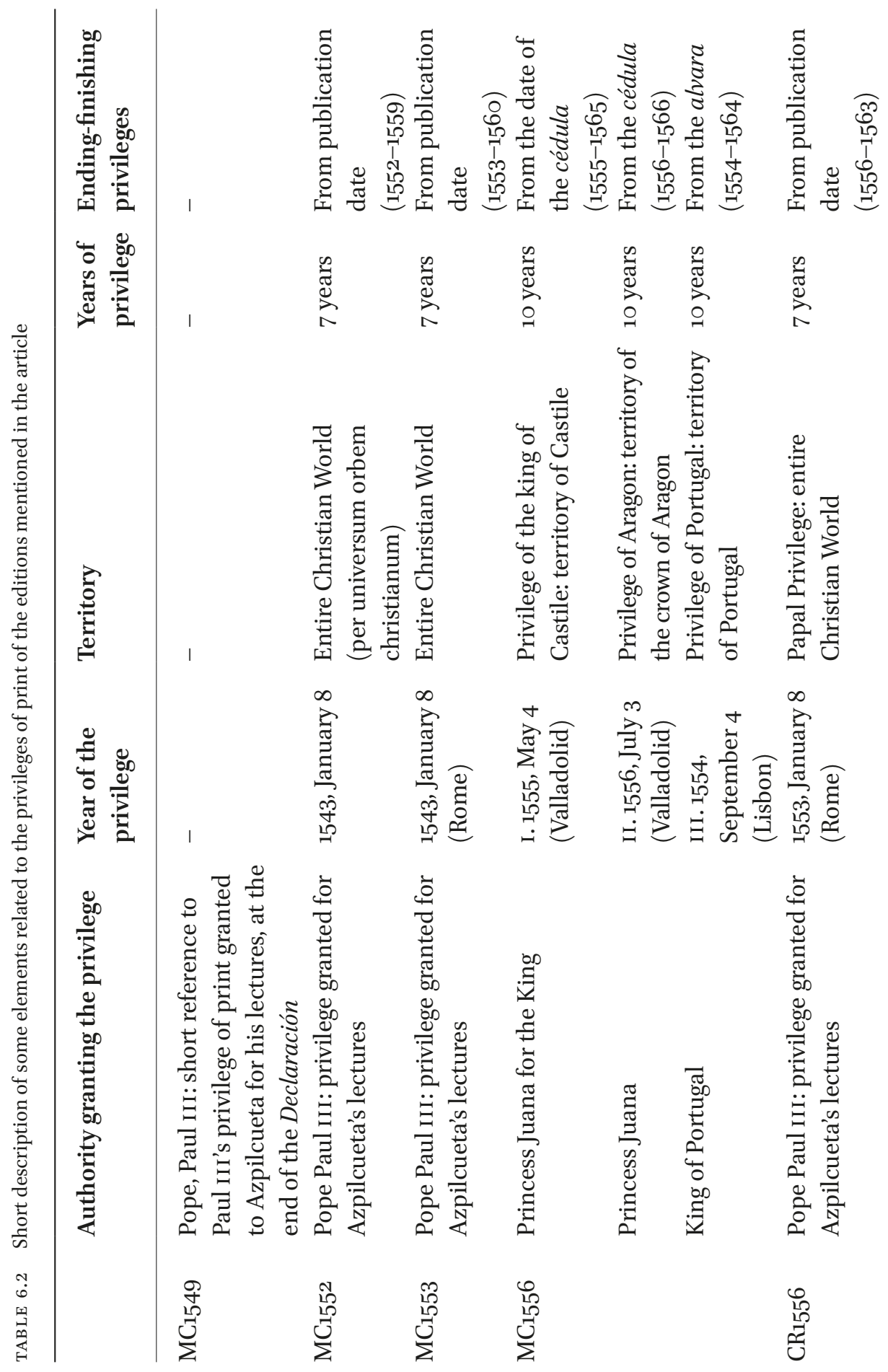




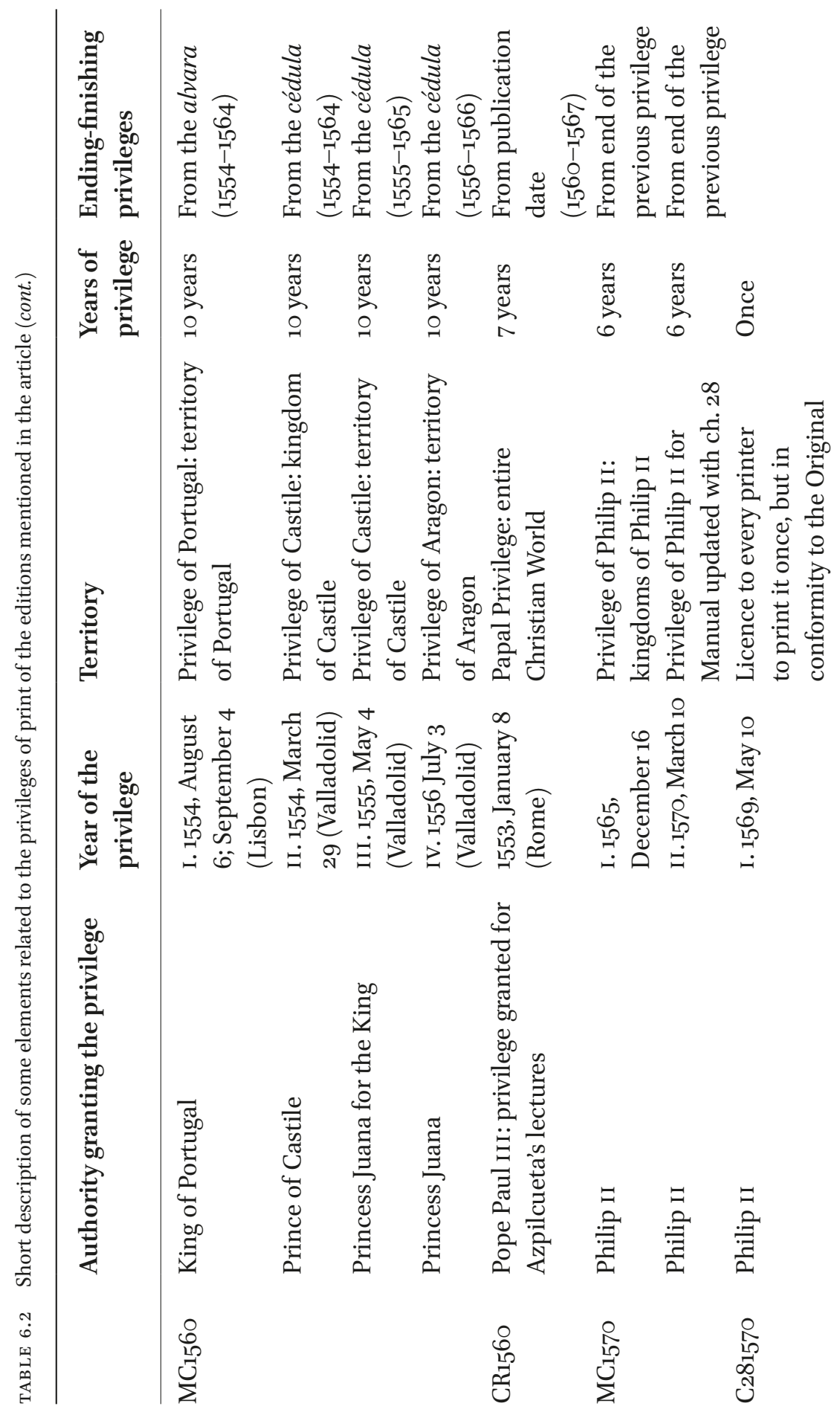



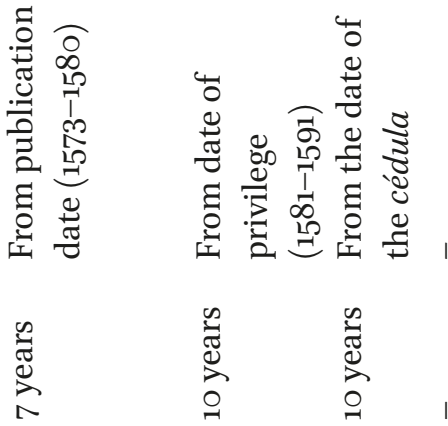

表穴

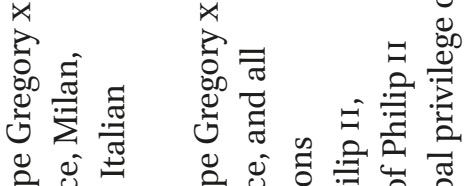

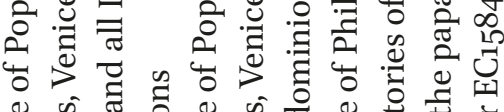

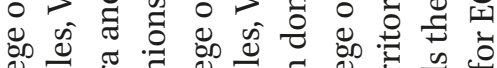

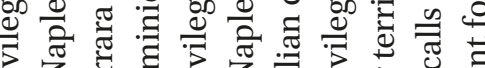

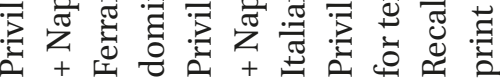

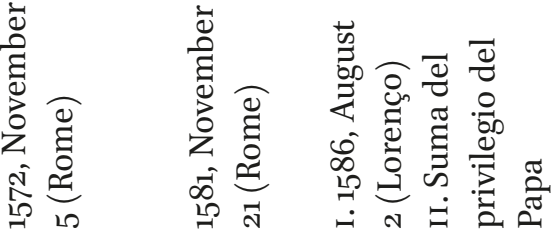

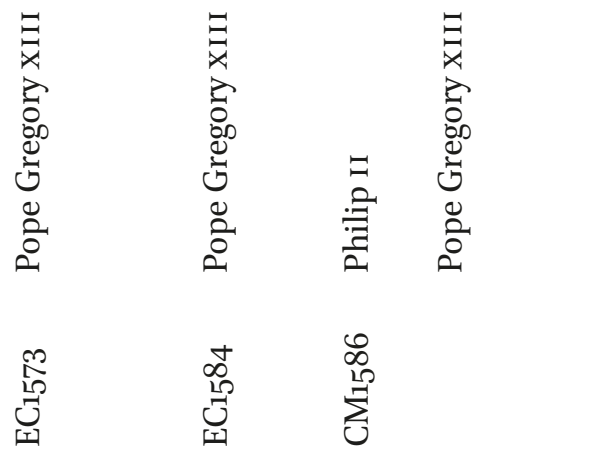



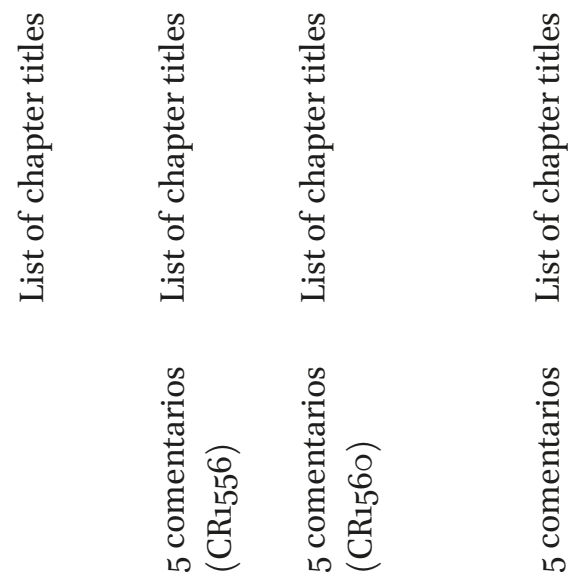

$\stackrel{5}{ \pm}$

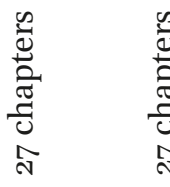

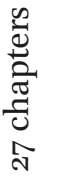

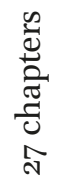

సิ

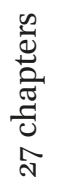

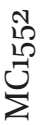

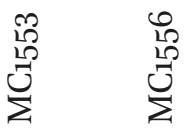

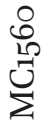

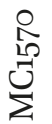



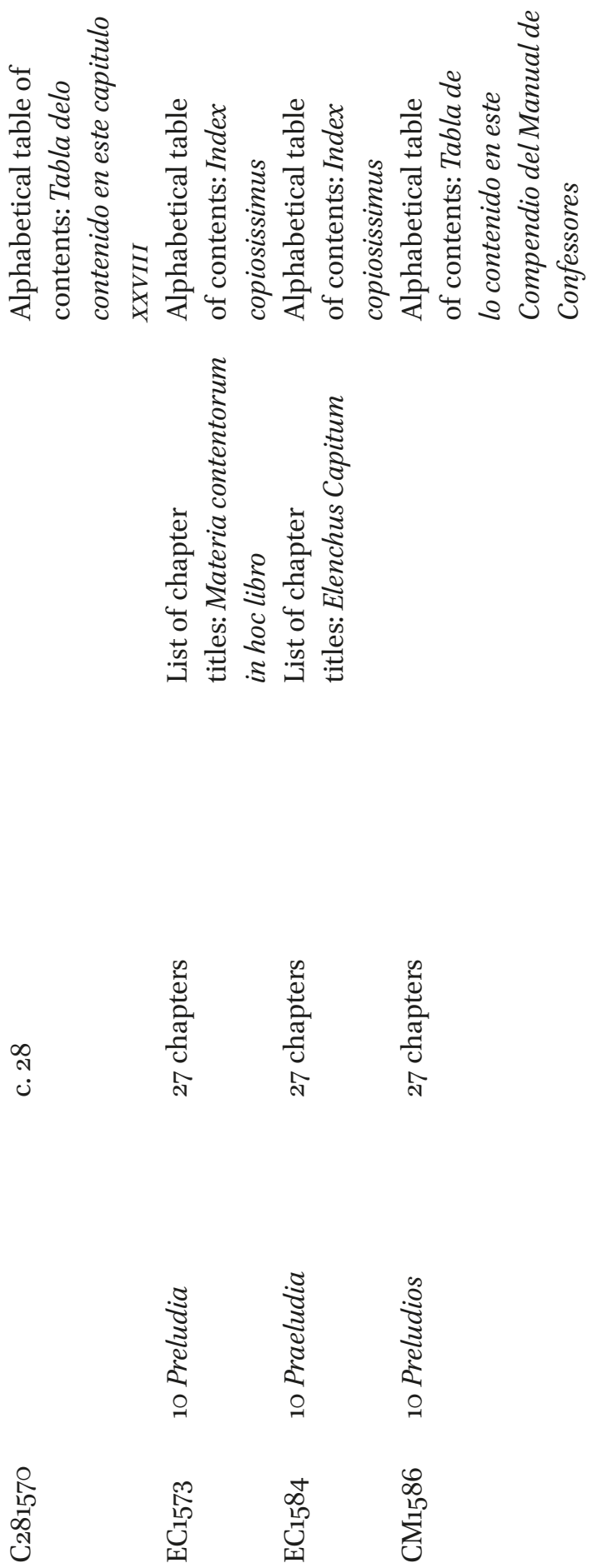
Compendio, more important than the reasons, the debates with other authors, or the motivation that grounded the arguments was the precept in itself, expressed without a margin of doubt.

Extracting the very essence of the updated and revised Manual constituted, one might say, the last and ulterior level of epitomisation. What could seem at first glance a simple and small book, with no erudite references, conceived to be understood by simple people, was actually the result of an extremely complex and life-long intellectual process. The famous portrait in the front-page can be understood as its adequate emblem. Traditionally, the picture is said to have been made unbeknown to Azpilcueta in the first years of his Roman stay. ${ }^{162}$ (Doctor Navarrus did not want to be portrayed, but his image could not lack in the galleries of viri illustres that decorated the libraries of some of the greatest collectors of the time, as well as the illustrated printed biographies of the 16th century.) The engraving of the front-page seems to testify not only to the authorship of the book but also to the fact that the entire erudition of the old and celebrated canonist had been condensed in the Compendio.

\section{Bibliography}

\section{Manuscripts}

Archivio Segreto Vaticano, Città del Vaticano (ASV), A.A. Arm. I-XVIII, 3129, cc. 1r-7v. Biblioteca Casanatense, Roma (BC), Ms. 740, сc. $3^{\text {r-203r. }}$

Biblioteca Pública de Évora, Évora (BPE), cod. CXvi/1-33, cc. 100-16o.

Universidade de Coimbra. Biblioteca Geral, Coimbra (UCBG), Ms. 1173, cc. 1r-65r.

\section{Printed Sources}

a) Azpilcueta's Works

[MC1549] Azpilcueta, Martín de and Rodrigo do Porto, Manual de confessores \& penitentes, Coimbra 1549: João de Barreira and João Alvares.

162 On Azpilcueta's portrait, dated 1572, which seems to have been commissioned by the Spanish theologian and great collector Alfonso Chacón during his stay in Rome, see Herkolz, "Alfonso Chacón e le gallerie dei ritratti nell'età della Controriforma". See also Ramlotaeus, Vita excellentissimi iuris monarchae Martini ab Azpilcueta Doctoris Navarri, who mentions the engraver Philippe de Soye as the artist who secretly sketched the portait, requested by the painter, illustrator, cartographer, print publisher, active in Rome, Antonio Lafreri. The portrait that was sold individually, appears also in some of the iconographic collections of viri illustres printed by Lafrery, namely attached to the collection of Illustrium iureconsultorum imagines (1566). See Rubach, Ant. Lafreri Formis Romae, 370. 
[MC1552] Azpilcueta, Martín de, Manual de confessores \& penitentes, Coimbra 1552: João de Barreira and João Alvares.

[MC1553] Azpilcueta, Martín de, Manual de confessores y penitentes, Coimbra 1553:João de Barreira and João Alvares.

[MC1556] Azpilcueta, Martín de, Manual de confessores y penitentes, Salamanca 1556: Andrea de Portonariis.

[CR1556] Azpilcueta, Martín de, Comentario resolutorio de usuras, Salamanca 1556: Andrea de Portonariis.

[MC1560] Azpilcueta, Martín de, Manual de confessores \& penitentes, Coimbra 156o: João de Barreira.

[C281570] Azpilcueta, Martín de, Capitulo XXVIII de las Addiciones de los XXVII capitulos del Manual de confessores y penitentes, Zaragoza 1570: En casa de la viuda de Bartholome de Nagera.

[MC1570] Azpilcueta, Martín de, Manual de confessores y penitenets con cinco Comentarios [...] Nuevamente Revisto, emendado, y anadido el Capitulo veynte y ocho, por el mesmo Autor, Valladolid 1570: Francisco Fernandez de Cordoua impressor de la Magestad Real. Vendese en la Libreria en casa de Antonio Suchet.

[EC1573] Azpilcueta, Martín de, Enchiridion sive Manuale confessariorum et poenitentium, Romae 1573: Victorium Elianum.

[EC1584] Azpilcueta, Martín de, Enchiridion, sive Manuale Confessariorum et poenitentium, Romae 1584: Ex Typographia Georgii Ferrarii.

[CM1586] Azpilcueta, Martín de, Compendio del Manual de Confessores y Penitentes, Valladolid 1586: En casa de Diego Fernández de Córdoua Impressor de Su Magestad. Por Antonio Suchet.

Azpilcueta, Martín de, In tres de poenitentiae distinctiones posteriores commentarii, Coimbra 1542: João de Barreira and João Alvares.

Azpilcueta, Martín de, Relectio cap. ita quorundam de Iudaeis, Conimbricae 1550: Ioannes Barrerius \& Ioannes Alvarus.

Azpilcueta, Martín de, Commentaria in septem distinctiones de Poenitentia, Romae 1581: Ex typographia Georgii Ferrarii.

Azpilcueta, Martín de, Consiliorum seu Responsorum, 2 vols., Venetiis 16o1: Apud Ioannem Guerilium.

Azpilcueta, Martín de, "Parescer del Doctor Nauarro sobre el decreto del Tridentino quanto a los cabildos", in Arigita y Lasa, Mariano (ed.), El doctor Navarro Don Martin de Azpilcueta y sus obras. Estudio histórico-crítico, Pamplona 1895, 585-6oo.

\section{b) Other Sources}

Beyerlinck, Laurens, Magnum theatrum vitae humanae, vol. 4, Lugduni 1665.

Brandão, Mário (ed.), Actas dos Conselhos da Universidade de 1505 a 1537, vol. 1, Coimbra 1941. 
Cartas Avulsas. Azpilcueta Navarro e outros. Cartas Jesuiticas 2, Coleção reconquista do Brasil. $2^{a}$ série, eds. Paim, Antonio, Roque Spencer, Maciel de Barros and Ruy Afonso da Costa Nunes, São Paulo 1988.

Conciliorum Oecumenicorum Decreta, ed. Istituto per le Scienze Religiose, 3rd ed., Bologna 1973.

Conciliorum Oecumenicorum Generaliumque Decreta, vol. 3: The Oecumenical Councils of the Roman Catholic Church. From Trent to Vatican II (1545-1965), eds. Ganzer, Klaus, Giuseppe Alberigo and Alberto Melloni, Turnhout 2010.

Gessner, Conrad, Pandectarum sive partitionum universalium Conradi Gesneri Tigurini, medici \& philosophiae professoris [...] libri XXI, Tiguri 1548: Excudebat Christophorus Froschuerus.

Gouvea, Francisco de, “'Antinavarrus', Introducción y edición de Estanislao Olivares S.I.", in Archivo teológico granadino 27 (1964), 271-384.

Leão, Duarte Nunes, Orthographia da lingoa portuguesa, obra util et necessaria assi pera bem escrever a lingoa Hespanhol, como a Latina, \& quaesquer outras que da Latina tem origen, Lisboa 1576: Ioao de Barreira.

Leite, Serafim (ed.), Monumenta Brasiliae, vol. 1: (1538-1553), Roma 1956.

Leite, Serafim (ed.), Monumenta Brasiliae, vol 2: (1553-1558), Roma 1957.

Machado, Diogo Barbosa, Bibliotheca Lusitana, vol. 1, Lisboa Occidental 1752: Antonio Isidoro da Fonseca.

Machado, Diogo Barbosa, Bibliotheca Lusitana, vol. 3, Lisboa 1741: Ignacio Rodriguez.

Marsilii von Inghen, Quaestiones super quatuor libros sententiarum, Argentinae 1501: Martinus Flach.

Monforte, Manoel de, Chronica da Provincia da Piedade primeira Capucha de Toda a ordem, e Regular Observancia de nosso Serafico Padre S. Francisco, Lisboa 1751: Na Officina de Miguel Manescal da Costa.

Monzón, Francisco de, Norte de confessores, Lisboa 1546: En casa de Luis Rodriguez librero del rey.

Ramlotaeus, Simon Magnus, Vita excellentissimi iuris monarchae Martini ab Azpilcueta Doctoris Navarri, Romae 1574: Apud Victorium Elianum.

Rëgo, António da Silva (ed.), Documentação para a história das missões do padroado português do Oriente, vol. 3: (1543-1547), Lisboa 1950.

Rëgo, António da Silva (ed.), Documentação para a história das missões do padroado português do Oriente, vol. 4: (1548-1550), Lisboa $195^{\circ}$.

Soto, Domingo de, Commentariorum [...] in Quartum Sententiarum. Tomus Primus, Salamanticae 1569: Apud Ioannem Baptistam à Terranova.

Vilas Boas, Manuel do Cenáculo, Memorias históricas do ministério do púlpito, Lisboa 1776: Na regia officina typografica.

Wicki, Josef (ed.), Documenta Indica, vol. 3: (1553-1557), Romae 1954.

Wicki, Josef and John Gomes (eds.), Documenta Indica, vol. 16: (1592-1594), Romae 1984. 


\section{Literature}

Abreu, Adélio Fernando, "O P. Manuel da Nóbrega e a evangelização dos indígenas do Brasil (1549-1570) (2). Os obstáculos à missão”, in Humanística e Teologia 34:2 (2013), 149-186.

Afanaseyev, Anton Alexandrovich, "La Escuela de Salamanca del siglo XVI: algunas contribuciones a la ciencia económica", in Revista Empresa y Humanismo 19:1 (2016), 7-30.

Andrés, Melquiades, La teología española en el siglo XVI, vol. 2, Madrid 1977.

Angelozzi, Giancarlo, "L'insegnamento dei casi di coscienza nella pratica educativa della Compagnia di Gesù", in Brizzi, Gian Paolo (ed.), La "Ratio Studiorum”. Modelli culturali e pratiche educative dei Gesuiti in Italia tra Cinque e Seicento, Roma 1981, 121-162.

Atienza, Julio de, Nobiliario Español. Diccionario heráldico de apellidos españoles y de títulos nobiliarios, Madrid 1948.

Baciero, Carlos, "La obra y sus fuentes”, in Baciero, Carlos, Jesús María García Añoveros, Francisco Maseda and Manuel Corrales (eds.), Alonso de la Peña Montenegro. Itinerario para párrocos de indios. Libros I-II, Madrid 1995, 57-71.

Barros, Cândida, "Intérpretes e confessionários como expressões de politicas linguísticas da Igreja voltadas à confissão", in DELTA 27:2 (2011), 289-310 (10.1590/So1O244502011000200005).

Barros, Maria Cândida Drumond Mendes, "Notas sobre os catecismos em línguas vernáculas das colônias portuguesas (séculos XVI-XVII)", in Iberoromania 57:1 (2003), 27-63.

Bataillon, Marcel, "Jeanne d'Autriche, Princesse de Portugal", in Bataillon, Marcel (ed.), Études sur le Portugal au temps de l'humanisme, Coimbra $195^{2}$.

Beck Varela, Laura, "The Diffusion of Law Books in Early Modern Europe: A Methodological Approach", in Meccarelli, Massimo and María Julia Solla Sastre (eds.), Spatial and Temporal Dimensions for Legal History. Research Experiences and Itineraries, Frankfurt am Main 2016, 195-239.

Belda Plans, Juan, Martín de Azpilcueta. El «Doctor Navavarro», Madrid 2015 (www.larramendi.es).

Blair, Ann M., Too Much to Know. Managing Scholarly Information before the Modern Age, New Haven, CT 2010.

Blair, Ann, "Humanism and Printing Press in the Work of Conrad Gessner", in Renaissance Quarterly 70 (2017), 1-37.

Blanco, Arturo, Historia del confesionario. Razones antropológicas y teológicas de su uso, Madrid 200o.

Boer, Wietse de, The Conquest of the Soul: Confession, Discipline, and Public Order in Counter-Reformation Milan, Leiden 2001.

Borromeo, Agostino, "Il concilio di Trento e la Riforma postridentina della penitenzeria apostolica (1562-1572)", in Sodi, Manlio and Johan Ickx (eds.), La penitenzeria 
apostolica e il sacramento della penitenza. Percorsi storici, giuridici, teologici e prospettive pastorali, Città del Vaticano 2009, 111-134.

Bragagnolo, Manuela, "Les voyages du droit du Portugal à Rome. Le 'Manual de confessores' de Martín de Azpilcueta (1492-1586) et ses traductions (The Travels of Law from Portugal to Rome. Martín de Azpilcueta's 'Manual de confessores' (1492-1586) and its Translations)", Max Planck Institute for European Legal History Research Paper Series No. 2018-13 (http://dx.doi.org/10.2139/ssrn.3287684).

Buescu, Ana Isabel, "Aspectos do Bilinguismo Português-Castelhano na época moderna", in Hispania 64:1, no. 216 (2004), 13-38.

Burke, Peter, Languages and Communities in Early Modern Europe, Cambridge 2004.

Burke, Peter, "Cultures of Translation in Early Modern Europe", in Burke, Peter and Ronnie Po-Chia Hsia (eds.), Cultural Translation in Early Modern Europe, Cambridge 2007, 7-38.

Burke, Peter, "Translations into Latin in early modern Europe", in Burke, Peter and Ronnie Po-chia Hsia (eds.), Cultural Translation in Early Modern Europe, Cambridge 2007, 65-8o.

Cantù, Francesca, La conquista spirituale. Studi sull'evangelizzazione del Nuovo Mondo, Roma 2007.

Carabias Torres, Ana María, "Castilla y Portugal: el trajín de la cultura académica”, in Espinosa, Rosa María and Julia Montenegro (eds.), Castilla y Portugal en los albores de la edad moderna, Valladolid 1997, 31-53.

Cardoso, Armando, "IV Centenario do P. João de Azpilcueta Navarro", in Verbum 15 (1958), 15-48.

Casetti Brach, C., "Eliano, Vittorio", in Istituto della Enciclopedia Italiana (ed.), Dizionario Biografico degli Italiani. Dugoni - Enza, vol. 42, Roma 1993, 475-477.

Castelnau-L'Estoile, Charlotte de, "Le mariage des infidèles au XVIe siècle: doutes missionnaires et autorité pontificale", in Mélanges de l'école française de Rome 121:1 (2009), 95-121.

Cevolini, Alberto, De arte excerpendi. Imparare a dimenticare nella modernità, Firenze 2006.

Condorelli, Orazio, "Le origini teologico-canonistiche della teoria delle leges mere poenales (secoli XIII-XVI)", in Schmoeckel, Mathias, Orazio Condorelli and Franck Roumy (eds.), Der Einfluss der Kanonistik auf die europäische Rechtskultur, vol. 3: Straf- und Strafprozessrecht, Köln 2012, 55-98.

Cordingley, Anthony, "Introduction", in Cordingley, Anthony (ed.), Self-Translation. Brokering Originality in Hybrid Culture, London 2013, 1-10.

Cordingley, Anthony and Céline Frigau Manning (eds.), Collaborative Translation. From the Renaissance to the Digital Age, London 2017.

Decock, Wim, Theologians and Contract Law. The Moral Transformation of the Ius Commune (ca.1500-1650), Leiden 2012. 
Decock, Wim, "Martín de Azpilcueta", in Domingo, Rafael and Javier Martínez-Torrón (eds.), Great Christian Jurists in Spanish History, Cambridge 2018, 116-132.

Dios de Dios, Salustiano de, "La doctrina sobre el poder del príncipe en Martín de Azpilcueta”, in Torijano Pérez, Eugenia, Salustiano de Dios de Dios and Javier Infante Miguel-Motta (eds.), El derecho y los juristas en Salamanca (siglos XVI-XX). En memoria de Francisco Tomás y Valiente, Salamanca 2004, 461-566.

Dunoyer, Emilio, L"Enchiridion Confessariorum' de Navarro, Pamplona 1957.

Duve, Thomas, "European Legal History - Concepts, Methods, Challenges", in Duve, Thomas (ed.), Entanglements in Legal History: Conceptual Approaches, Frankfurt am Main 2014, 29-66.

Ellsworth Hamann, Byron, The Translations of Nebrija. Language, culture, and circulation in the Early Modern World, Amherst, MA 2015.

Fernandes, Maria de Lurdes Correia, "As artes da Confissão. Em torno dos manuais de confessores do século XVI em Portugal”, in Humanística e Teologia 11 (1990), 47-80.

Fernandes, Maria de Lurdes Correia, "Do manual de confessores ao guia de penitentes. Orientações e caminhos da confissão non Portugal post-Trento", in Via Spiritus 2 (1990), 47-65.

Fernandes, Maria de Lurdes Correia, "Francisco de Monzón, capelão e pregador de D. João III e de D. Sebastião", in Lusitania Sacra, 2 ${ }^{a}$ série, 3 (1991), 37-9o.

Fery-Hue, Françoise (ed.), Traduire de vernaculaire en latin au Moyen Âge et à la Renaissance. Méthodes et finalités, Paris 2013.

Fonseca, Fernando Taveira da, José Antunes, Irene Vaquinhas, Isabel Nobre Vargues, Luís Reis Torgal and Fernando J. Regateiro, Imprensa da Universidade de Coimbra. Uma história dentro da História, Coimbra 2001.

Fragnito, Gigliola, La Bibbia al rogo. La censura ecclesiastica e i volgarizzamenti della sacra scrittura, Bologna 1997.

García y García, Antonio, "Juristas Salamantinos, siglos XVI-XVII: Manuscritos y impresos", in Rodríguez-San Pedro Bezares, Luis E. and Ángel Weruaga Prieto (eds.), Historia de la Universidad de Salamanca. Saberes y confluencias, vol. 3.1, Salamanca 2018, 139-170.

Goering, Joseph, "The Internal Forum and the Literature of Penance and Confession", in Hartmann, Wilfried and Kenneth Pennington (eds.), The History of Medieval Canon Law in the Classical Period, 1140-1234. From Gratian to the Decretals of Pope Gregory IX, Washington, D.C. 2008, 379-428.

Grossi, Paolo, "Somme penitenziali, diritto canonico, diritto comune", in Annali della facoltà giuridica. Università di Macerata 1 (1966), 94-134.

Grossi, Paolo, "Somme penitenziali, diritto canonico, diritto comune", in Fantappiè, Carlo (ed.), Scritti canonistici, vol. 1, Milano 2013, 115-153.

Guedes de Campos, Fernanda Maria, A ordem das ordens religiosas. Roteiro Identitário de Portugal (Séculos XII-XVIII), Casal de Cambra 2017. 
Hamesse, Jacqueline, "Il modello della lettura nell'età della scolastica", in Cavallo, Guglielmo and Roger Chartier (eds.), Storia della lettura nel mondo occidentale, Laterza 1995, 91-116.

Herkolz, Ingo, “Alfonso Chacón e le gallerie dei ritratti nell'età della Controriforma”, in Tosini, Patrizia (ed.), Arte e committenza nel Lazio nell'età di Cesare Baronio, Roma 2009, 111-142.

Hespanha, António Manuel, "Form and content in early modern legal books. Bridging the gap between material bibliography and the history of legal thought", in Rechtsgeschichte 12 (2008), 12-50.

Hokenson, Jan Walsh and Marcella Munson, The Bilingual Text. History and Theory of Literary Self-Translation, Manchester 2007.

Infantes, Víctor, Del libro áureo, Madrid 2006.

Johns, Adrian, The Nature of the Book. Print and Knowledge in the Making, Chicago, IL 1998.

Lavenia, Vincenzo, "Martín de Azpilcueta (1592-1586). Un profilo", in Archivio Italiano per la Storia della Pietà 16 (2003), 15-157.

Lavenia, Vincenzo, L'infamia o il perdono. Tributi, pene e confessione nella teologia morale della prima età moderna, Bologna 2004.

Leite, Serafim, História da Companhia de Jesus no Brasil, vol. 2: Século XVI - a obra, Lisboa 1938.

Leite, Serafim, História da Companhia de Jesus no Brasil, vol. 8: Escritores: de A a M. (Suplemento Biobibliográfico - I), Rio de Janeiro 1949.

López Gay, Jesús, "La primera biblioteca de los Jesuítas en el Japón (1556). Su contenido y su influencia", in Monumenta Nipponica 15:3-4 (1959-196o), 350-379.

Marcocci, Giuseppe, I custodi dell'ortodossia. Inquisizione e chiesa nel Portugallo del Cinquecento, Roma 2004.

Marcocci, Giuseppe, L'invenzione di un impero. Politica e cultura nel mondo portoghese (1450-160o), Roma 2011.

Marques, João Francisco, "Franciscanos e Dominicanos Confessores dos Reis Portugueses das duas Primeiras Dinastias. Espiritualidade e Política”, in Revista da Faculdade de Letras - Línguas e Literatura Anexo V - Espiritualidade e corte em Portugal (sécs XVI-XVIII) (1993), 53-6o.

Mateu y Llopis, Felipe, "Licencia, tasa y privilegio de impresion en la España de los siglos XVI y XVII”, in Gutenberg-Jahrbuch 40 (1965), 197-200.

McKenzie, D.F., Bibliography and the Sociology of Texts, London 1986.

Michaud-Quantin, Pierre, Sommes de casuistique et manuels de confession au moyen âge (XII-XVI siècles), Louvain 1962.

Minnis, A.J., "Late Medieval Discussions on Compilatio and the Role of Compilator", in Beiträge zur Geschichte der deutschen Sprache und Literatur 101 (1979), 385-421. 
Muguruza Roca, Isabel, "Del confesionario ibérico de la Contrarreforma a los manuales para confesores en la América colonial: el Manual de confesores y penitentes de Martín de Azpilcueta como texto de referencia", in Indiana 32:5 (2018), 29-53.

Muñoz de Juana, Rodrigo, Moral y economía en la obra de Martín de Azpilcueta, Pamplona 1998.

O’Banion, Patrick J., “'A priest who appears good'. Manuals of confession and the construction of clerical identity in early modern Spain", in Dutch Review of Church History 85:1 (2005), 333-348.

O'Malley, John W., The First Jesuits, Cambridge 1993.

Paiva, José Pedro, "Bispos, imprensa, livro e censura no Portugal de Quinhentos", in Revista de Historia das Ideas 28 (2007), 687-737.

Palacín, L., “Azpilcueta (Navarro), Juan de”, in O’Neill, Charles Edwards and Joaquín María Domínguez (eds.), Diccionario histórico de la Compañía de Jesús, vol. 1, Roma 2001, 317.

Polónia, Amélia, "Recepção do Concilio de Trento em Portugal: as normas enviadas pelo Cardeal D. Henrique aos Bispos do reino, em 1553", in Revista da Faculdade de Letras-Historia, $2^{\text {a }}$ série, 7 (1990), 133-143.

Polónia, Amélia, D. Henrique. O Cardeal-Rei, Lisboa 2005.

Polónia, Amélia, "Espaços de intervenção religiosa do Cardeal Infante D. Henrique: actuação pastoral, reforma monástica e inquisição”, in Amorim, Inês, Helena Osswald and Amélia Polónia (eds.), Em torno dos espaços religiosos - monásticos e eclesiásticos. Actas do colóquio de homenagem a Frei Geraldo Coelho Dias, Porto 2005, 17-37.

Prodi, Paolo, Una storia della giustizia. Dal pluralismo dei fori al moderno dualismo tra coscienza e diritto, Bologna 2000.

Prodi, Paolo, Settimo non rubare. Furto emercatonella storia dell'occidente, Bologna 2009.

Réach-Gnô, Anne, "De la catégorisation bibliothéconomique du livre à la genèse éditoriale de l'oeuvre: le cas des Trésors imprimés à la Renaissance", in Seizième Siècle 10 (2014), 211-224.

Réach-Ngô, Anne, "Du texte au livre, et retour: la production littéraire à la Renaissance, une création collaborative?”, in Genesis 41 (2005), 29-47.

Reyes Gómez, Fermín de los, "Con privilegio: la exclusiva de edición del libro antiguo español”, in Revista General de Información y Documentación 11:2 (2001), 163-200.

Reyes Gómez, Fermín de los, "La estructura formal del libro antiguo español”, in Paratesto 7 (2010).

Ridruejo, Emilio, "Castellano y portugués en la época de los descubrimientos", in Sociedad V Centenario Tratado de Tordesillas (ed.), La lengua española y su expansión en la época del Tratado de Tordesillas, Valladolid 1995, 65-78.

Rivara, Joaquim Heliodoro da Cunha, Catalogos manuscriptos da biblioteca publica eborense, vol. 1, Lisboa 185 o. 
Rodrigues, Manuel Augusto (ed.), Memoria professorum Universitatis Conimbrigensis, vol. 1: (1290-1772), Coimbra 2003.

Rodríguez-San Pedro Bezares, Luis E. and Ángel Weruaga Prieto (eds.), Historia de la Universidad de Salamanca. Indice y figuras, vol. 5, Salamanca 2018.

Rouse, Richard H. and Mary A. Rouse, "Statim invenire. Schools, Preachers, and New Attitudes to the Page", in Benson, Robert L. and Giles Constable (eds.), Renaissance and Renewal in the Twelfth Century, Cambridge, MA 1982, 201-225.

Rubach, Birte, Ant. Lafreri Formis Romae. Der Verleger Antonio Lafreri und seine Druckgraphikproduktion, Berlin 2016.

Ruiz Fidalgo, Lorenzo, La imprenta en Salamanca (1501-160o), vol. 1/3, Madrid 1994.

Serrão, Joaquim Veríssimo, "Portugueses no Estudo de Salamanca (1250-1550)", in Revista da Faculdade de Letras, $3^{\text {a }}$ série, 5 (1962), 1-515.

Silva, António Pereira da, "A primeira suma portuguesa de teologia moral e sua relação com o «Manual» de Navarro", in Didaskalia 5:2 (1975), 355-403.

Simón Díaz, José, El libro español antiguo, Madrid 2000.

Solinas Quijada, Francisco, "El doctor Martín de Azpilcueta en la Universidad de Coímbra", in Principe de Viana 47 (1986), 6o9-640.

Tejero, Eloy, "Martín de Azpilcueta en la historia de la doctrina canónica y moral", in Ius Canonicum 27:54 (1987), 425-492.

Tejero, Eloy, "Martín de Azpilcueta cinco veces universitario", in Linehan, Peter (ed.), Life, Law and Letter: Historical Studies in Honour of Antonio García y García, Roma 1998, 839-862.

Tejero Tejero, Eloy, “Azpilcueta, Martín de”, in Real Academia de la Historia (ed.), Diccionario biográfico español, vol. 6: De 'Asuero Sáenz de Cenzano' a 'Barco y Gasca', Madrid 2009, 430-433.

Tentler, Thomas N., Sin and Confession in the Eve of the Reformation, Princeton, NJ 1977.

Turrini, Miriam, La coscienza e le leggi. Morale e diritto nei testi per la confessione della prima età moderna, Bologna 1991.

Waquet, Françoise, Latin or the Empire of a Sign. From the Sixteenth to the Twentieth Century, trans. John Howe, London 2001.

Xavier, Ângela Barreto, "Itinerários Franciscanos na Índia Seiscentista e algumas questões de história e de método", in Lusitânia Sacra, $2^{\mathrm{a}}$ série, 18 (2016), 87-116. 